\title{
PREARRAIGNMENT INTERROGATION AND THE MCNABB- MALLORY MIASMA: A PROPOSED AMENDMENT TO THE FEDERAL RULES OF CRIMINAL PROCEDURE
}

UNDER rule 5(a) of the Federal Rules of Criminal Procedure, "an officer making an arrest" must bring the arrested person before a United States commissioner or other committing official "without unnecessary delay." Complying with rule $5(\mathrm{~b})$, the commissioner will then advise the accused of his privilege against self-incrimination, his right to retain counsel, and his right to a preliminary hearing ${ }^{2}$ for determining whether "there is probable cause

1. Appearance before the Commissioner. An officer making an arrest under a warrant issued upon a complaint or' any person making an arrest without a warrant shall take the arrested person without unnecessary delay before the nearest available commissioner or before any other nearby officer empowered to commit persons charged with offenses against the laws of the United States. When a person arrested without a warrant is brought before a commissioner or other officer, a complaint shall be filed forthwith.

FED. R. CRIM. P. 5(a).

Rule 5(a) applies exclusively to arrests made upon a warrant issued on a complaint, see FED. R. Crim. P. 3, 4, or without a warrant. See generally Orfield, Warrant of Arrest and Sumnons Upon Complaint in Federal Criminal Procedure, 27 U. Cinc. L. Rev. 1 (1958); Orfield, The Complaint in Federal Criminal Procedure, 46 KY. L.J. 7 (1957). When arrest is made upon a warrant issued on an indictment or information, the accused is to be brought "promptly" before a federal court or commissioner for purposes of bail. FED. R. CRIM. P. 9(c)(1). See generally Orfield, Warrant or Summons Upon Indictment or Information in Federal Criminal Procedure, 23 Mo. L. Rev. 308 (1958).

Officers empowered to commit persons charged with federal offenses include state judges, justices of the peace and other state magistrates. 18 U.S.C. $\$ 3041$ (1952). Apparently, arresting officers complying with rule 5(a) may bring the accused to either a state or federal committing official so long as such official is nearby. See Gold, Confessions in the United States Courts, 21 PA. B.A.Q. 272 (1950).

2. Statement by the Commissioner. The commissioner shall inform the defendant of the complaint against him, of his right to retain counsel and of his right to have a preliminary examination. He shall also inform the defendant that he is not required to make a statement and that any statement made by him may be used against him. The commissioner shall allow the defendant reasonable time and upportunity to consult counsel and shall admit the defendant to bail as provided in these rules.

Fk. . R. Ckrm. P. 5(b). See also United States v. Bradford, 122 F. Supp. 915, 919 (S.D. N.Y. 1954) ; U.S. Judictal Conference, Consm. on U.S. Commissioners, Manual for United States Commissioners 8-9 (rev. ed. 1948).

The accused has no constitutional right to a preliminary hearing. United States $e x$ rel. Hughes v. Gault, 271. U.S. 142, 149 (1926) ; Clarke v. Huff, 119 F.2d 204 (D.C. Cir. 1941); Garrison v. Johnston, 104 F.2d 128 (9th Cir. 1939). And failure to grant him one does not invalidate his prosecution. United States ex rel. Bogish v. Tees, 211 F.2d 69, 72 (3d Cir. 1954) (indictment); Davis v. United States, 210 F.2d 118, 120 (8th Cir. 
to believe" that he committed a crime. ${ }^{3}$ At the preliminary hearing, both the accused and the Government may present evidence. ${ }^{4}$ If the commissioner finds "probable cause," the accused must be either admitted to bail or committed to the custody of a United States marshal for detention." Absent "probable

1954) (indictment) ; United States v. Pickard, 207 F.2d 472, 474 (9th Cir. 1953) (information).

The commissioner may grant a continuance to enable either side to prepare its case. James v. Lawrence, 176 F.2d 18 (D.C. Cir. 1949); United States v. Gray, 87 F. Supp. 436 (D.D.C. 1949). But see Lloyd v. United States, 259 F.2d 334 (D.C. Cir. 1958) (concurring opinion). During a continuance, the accused may be indicted by a grand jury, and no preliminary hearing need be held. United States v. Gray, supra. But see concurring opinion in Lloyd v. United States, supra.

State judges and magistrates acting as committing officers under rule 5(a) are not bound to hold the preliminary hearing which the Federal Rules of Criminal Procedure provide for. See FED. R. CRIM. P. 54(a) (2). They may proceed according to the law of their respective jurisdictions. 18 U.S.C. $\$ 3041$ (1952). Since arresting officers are not bound to bring the accused to a United States commissioner rather than a state official, see note 1 supra, the purpose of rule 5(b) may thus be thwarted.

Rule 5 (b) provides only for retained and not assigned counsel. Notes of Advisory Committee on Rules, FED. R. CRIM. P. 44. Usually, the accused has no constitutional right to counsel at the preliminary hearing. Burall v. Johnston, $53 \mathrm{~F}$. Supp. 126, 12y (N.D. Cal. 1943), aff'd, 146 F.2d 230 (9th Cir. 1944), cert. denied, 325 U.S. 887 (1945) ; In re Bates, 2 Fed. Cas. 1015 (No. 1099a) (D.S.C. 1858) ; United States v. Bollman, 24 Fed. Cas. 1189, 1191 n.2 (No. 14622) (C.C.D.D.C. 1807). He may have such a right if the absence of an attorney unduly prejudices him at trial. Wood v. United States, 128 F.2d 265, 271. (D.C. Cir. 1942). Subsequent representation by counsel will seemingly cure any prejudice incurred at the preliminary hearing. See Canizio v. New York, 327 U.S. 82 (1946); Alexander v. United States, 136 F.2d 783 (D.C. Cir. 1943) ; McJordan v. Huff, 133 F.2d 408 (D.C. Cir. 1943) ; Application of Lyda, 154 F. Supp. 237, 238 (N.D. Cal. 1957).

3. Preliminary Examination. The defendant shall not be called upon to plead. If the defendant waives preliminary examination, the commissioner shall forthwith hold him to answer in the district court. If the defendant does not waive examination, the commissioner shall hear the evidence within a reasonable time. The defendant may cross-examine witnesses against him and may introduce evidence in his own behalf. If from the evidence it appears to the commissioner that there is probable cause to believe that an offense has been committed and that the defendant has committed it, the commissioner shall forthwith hold him to answer in the district court; otherwise the commissioner shall discharge him. The commissioner shall admit the defendant to bail as provided in these rules. After concluding the proceeding the commissioner shall transmit forthwith to the clerk of the district court all papers in the proceeding and any bail taken by him.

Fed. R. Crm. P. 5(c).

4. Ibid. As to whether strict rules of evidence apply at the preliminary examination, compare In re Van Campen, 28 Fed. Cas. 954, 955 (No. 16835) (S.D.N.Y. 1868), with In re Dana, 68 Fed. 886, 896 (S.D.N.Y. 1895). State courts are in similar conflict. Compare In re Plummer, 79 Cal. App. 2d 651, 655, 180 P.2d 771, 775 (1947), with Davis v. State, 65 So. 2d 307 (Fla. 1953), and People v. Medley, 339 Mich. 486, 492, 64 N.W. 2d 708, 712 (1954).

5. See Fed. R. CRIN. P. 5(c), supra note 3; Fed. R. CRIM. P. 46(a) (1) (right to bail) ; 18 U.S.C. $\$ \$ 4042,4086$ (1952) (place of commitment) ; U.S. JudrCIAL ConreR- 
cause," the accused must be discharged. ${ }^{6}$ Should the preliminary hearing be waived, the accused will be immediately jailed or bailed. ${ }^{7}$

Police officials claim that effective interrogation is possible only during the interval between arrest and arraignment by a committing officer. ${ }^{8}$ In order to take full advantage of this opportunity to interrogate, law enforcement agents have frequently ignored the command of rule 5(a) and have delayed arraignment for substantial periods of time. ${ }^{9}$ To deter infractions of this sort, the Supreme Court held in $M c N a b b$ v. United States that incriminating statements obtained from an accused illegally detained between arrest and arraignment are inadmissible in United States courts. ${ }^{10}$

ence, Comm. on U.S. Commissioners, Manual for United States Commissioners 12-18 (rev. ed. 1948) (administration of bail and commitment by the commissioner). "Probable cause" may be established by evidence insufficient to convict. United States v. Slaugenhoupt, 102 F. Supp. 820 (W.D. Pa. 1952) (existence of indictment sufficient); United States v. Bloomgart, 24 Fed. Cas. 1180 (No. 14612) (S.D.N.Y. 1868) (no proof of corpus delicti); United States v. Cobb, 25 Fed. Cas. 481 (No. 14820) (N.D.N.Y. 1857) (prima facie evidence of guilt). A commissioner's finding of "probable cause" is reviewable. United States v. Zerbst, 111 F. Supp. 807 (E.D.S.C. 1953).

6. FED. R. Crim. P. 5(c), supra note 3.

7. Ibid. For the effect of a waiver on defects in the arrest or complaint, see Giordenello v. United States, 241 F.2d 575 (5th Cir. 1957); United States v. Walker, 197 F.2d 287 (2d Cir.), ccrt. denied, 344 U.S. 877 (1952).

8. See Hearings Before Subcommittee No. 2 of the House Committee on the Judiciary on H.R. 3690, 78th Cong., 1st Sess., ser. 12, at 6-7 (1944) [hereinafter cited as 1944 Hearings]; Hearings Before the Special Subcommittee to Study Decisions of the Supreme Court of the United States of the House Committee on the Judiciary, 85th Cong., 2d Sess., ser. 12, at 40, 42 (1958) [hereinafter cited as 1958 House Hearings]. Arraignment before the commissioner also ends the danger of "third degree" practices. A Memorandum on the Detention of Arrested Persons Accompanying a StateMent By the Committee on the Bill of Rights of the American Bar Assoctation oN H.R. 3690, at 15-17 (1944) [hereinafter cited as ABA Statement] ; 4 NAT'L Comin'N ON LAw ORSERVANCE AND ENFORCENENT, REPORT 169, 210-11 (1931) [hereinafter cited as Wickersham Report] ; Hopkins, Our Lawless Police 131 (1931).

The term "arraignment" is used in this Comment to designate the initial appearance of the accused before a committing officer. See Orfield, Proceedings Before the Commissioner in Federal Crininal Procedure, 19 U. PITT. L. Rev. 489, 504 \& nn.45-48, 538 \& n.332 (1958). The same word has been traditionally used to describe the appearance of the accused before the court in order to plead in answer to formal charges. E.g., FED. R. CRIM. P. 10.

9. See, e.g., Rettig v. United States, 239 F.2d 916, 920-21. (D.C. Cir. 1956) (28 hours) ; United States v. Leviton, 193 F.2d 848 (2d Cir. 1951) (29 hours); Haines v. United States, 188 F.2d 546 (9th Cir. 1951) (23 hours); cf. AxrERICAN CIVIL LIBERTIES Unian, Illinois Division, Secret Detention by the Chicago Police (1959).

10. 318 U.S. 332 (1943). The $M c N a b b$ rule has been interpreted also to exclude incriminating evidence other than statements obtained from the accused during an unlawful delay. United States v. Klapholz, 230 F.2d 494, 498 (2d Cir. 1956) (testimony concerning phone calls to accused detained in his own apartment), criticized in Note, 66 YALE L.J. 270; Watson v. United States, 249 F.2d 106, 109 (D.C. Cir. 1957) (clothing). But the rule does not exclude exculpatory statements. Starr v. United States, No. 13865, D.C. Cir., Oct. 17, 1958, at 3-4. Nor will a confession lawfully elicited but apparently 
The $M c N a b b$ rule represents an exercise of the Court's supervisory power over the administration of criminal justice in federal courts and a fulfillment of its duty to formulate civilized standards of procedure and evidence. ${ }^{11}$ The purpose of federal prompt-arraignment legislation, ${ }^{12}$ in the view of the Court, is to check resort to coercion and brutality and to avoid the evil implications of secret interrogation. ${ }^{13}$ From this premise, the Court reasoned that the admission of material evidence obtained in contravention of a law requiring prompt arraignment would stultify the policy underlying the law. ${ }^{14}$ By thus compelling compliance with restrictions upon prearraignment detention, the Court sought to forestall delays frequently leading to the elicitation of evidence in a manner violating due process of law. ${ }^{15}$ The exclusion of evidence

derived from a previous illegally obtained confession be excluded. United States v. Bayer, 331 U.S. 532, 540-41 (1947). Whether nonconfessional evidence derived through the elicitation of confessional or nonconfessional evidence in violation of rule 5 (a) is inadmissible has yet to be decided. See Comment, 53 Y YLE L.J. 758, 772 (1944); Note, 47 CoL.uMr. L. REv. 1214, 1218 (1947). Language in the Bayer case indicated that if the subsequent evidence is nonconfessional, it might be excluded by analogy to wire-tapping cases such as Nardone v. United States, 308 U.S. 338 (1939). United States v. Bayer, supra at 541 .

11. MeNabb v. United States, 318 U.S. 332, 340 (1943) ; cf. Nardone v. United States, 308 U.S. 338, $341-42$ (1939); Wolfle v. United States, 291 U.S. 7 (1934); Funk v. United States, 290 U.S. 371. (1933). See generally 1 WIGMoRE, Evidence $\$ \S 6-6 b$ (3d ed. 1940).

12. $M c N a b b$ was decided before the Federal Rules of Criminal Procedure were formulated. The Court relied upon 28 Stat. 416 (1894), which required arresting officers to bring the accused before a judicial officer for a hearing. Although the statute made no mention of promptness, courts had read into it a prohibition against "unnecessary delay." Bullock v. United States, 122 F.2d 213 (D.C. Cir. 1941); United States $e x$ rel. Humphrey v. Janus, 30 F.2d 530 (E.D. Idaho 1929), rev'd on other grounds, 38 F.2d 431 (9th Cir. 1930). The Court also mentioned 48 Stat. 1008 (1934) (F.B.I. must take arrested persons "immediately" before a committing officer); 20 Stat. 342 (1879) (persons arrested while operating an illicit distillery must be brought "forthwith" to a judicial officer); and a host of state statutes. McNabb v. United States, 318 U.S. 332, 342 n.7 (1943). For a discussion of the legislative history of the federal statutes mentioned in $M C N a b b$, see Inbau, The Confession Dilemma in the United States Supreme Court, 43 ILL. L. REv. 442, 455-59 (1949). For a compilation of state prompt-arraignment laws, see Hearings on Confessions and Police Detention Before the Subcommittee on Constitutional Rights of the Senate Committee on the Indiciary, 85th Cong., 2d Sess. 735-4S (1958).

13. McNabb v. United States, supra note 12, at 344.

14. Id. at 345 .

15. See Mallory v. United States, 354 U.S. 449, 453 (1957) ("wilful disobedience of law" evoked exclusion in $M c N a b b$ because "unwarranted detention led to tempting utilization of intensive interrogation easily gliding into the evils of "the third degree"); United States v. Carignan, 342 U.S. 36, 44-45 (1951) (purpose of $M c N a b b$ was to abolish unlawful detention "thought to give opportunity for improper pressure by police before the accused had the benefit of the statement by the commissioner"); Brown v. Allen, 344 U.S. 443, 476 (1953) ( $\mathrm{McNabb}$ sought "to abolish the opportunities for cuercion which prolonged detention without a hearing is said to enhance"); Upshaw v. United States, 335 U.S. 410,412 (1948) ( $1 I c N a b b$ designed to check resort by officers to "secret 
obtained in derogation of the procedural proscription against "unnecessary delay" is not, however, constitutionally required. ${ }^{\mathbf{1 6}}$

The short life of the $M c N a b b$ rule has not been an altogether happy one. The Supreme Court's development of the rule has been hesitant and imprecise, the lower courts', confusing and inconsistent. ${ }^{17}$ To begin with, the $M c$ $N a b b$ decision itself indicates both that incriminating statements are inadmissible solely because they were obtained during an illegal delay, and, contradictorily, that the presence of potentially coercive activity during detention is a prerequisite to exclusion. ${ }^{18}$ Subsequent Supreme Court decisions intro-

interrogation of persons accused of crime"); Note, 66 Y YLE. L.J. 270, 277 n.29 (1956) (collecting authorities). But see Hogan \& Snee, The McNabb-Mallory Rule: Its Rise, Rationale and Resctle, 47 GEo. L.J. 1, 32 (1958) (McNabb designed to avoid debasement of judicial process by excluding evidence obtained in contravention of law).

The Court noted in $M c N a b b$ that it need not reach any constitutional issue. 318 U.S. at 340 . Petitioners claimed that their admissions were not made voluntarily and therefore should have been excluded from evidence. Memorandum for Petitioner, pp. 2, 6, McNabb v. United States, 318 U.S. 332 (1943). A new trial was requested on the ground that government agents had committed manifest violations of the fifth amendment, but no specific clause in the amendment was relied upon. $I d$. at 6 . Petitioners were apparently understood to claim a violation of due process, see 318 U.S. at 339-40, rather than an abrogation of the privilege against self-incrimination. See Bram v. United States, 168 U.S. 532, 542 (1897).

The Court has never used the fifth amendment's due process clause to hold extrajudicial incriminating statements inadmissible. It has preferred in federal cases to rely upon nonconstitutional rules of evidence. Ziang Sung Wan v. United States, 266 U.S. 1 (1924); Wilson v. United States, 162 U.S. 613 (1896); Hardy v. United States, 186 U.S. 224 (1902). But see Bram v. United States, supra at 542 (confession excluded as violating privilege against self-incrimination). Nevertheless, the nonconstitutional test used in federal cases is the same as that applied by the Court in state cases in which a violation of fourteenth amendment due process is claimed. Inbau, supra note 12, at 448; Note, 66 Yale L.J. 270, 278 n.32 (1956); Note, 5 Stan. L. Rev. 459, 460 n.9 (1953). The fourteenth amendment prohibits the admission of involuntarily given incriminating statements. E.g., Brown v. Mississippi, 297 U.S. 278 (1936); Leyra v. Denno, 347 U.S. 556 (1954). To be "voluntary" an incriminating statement must be elicited by methods which do not cast doubt on its reliability and which do not offend standards of fundamental fairness. See note 122 infra and accompanying text. For purposes of this Comment, the term "coercion" refers to methods rendering a statement "involuntary."

16. Crooker v. California, 357 U.S. 433, 439 n.4 (1958) ; Brown v. Allen, 344 U.S. 443, 476 (1953); Gallegos v. Nebraska, 342 U.S. 55, 63-64 (1951). Not constrained under the fourteenth amendment to adhere to the $M c N a b b$ doctrine, state courts have been uniformly reluctant to adopt a similar rule. See, e.g., State v. Jordan, 83 Ariz. 248, 320 P.2d 446, cert. denticd, 357 U.S. 922 (1958); People v. Searcy, 153 Cal. App. $2 d$ 799, 314 P.2d 1002 (1957); State v. Zukauskas, 132 Conn. -450, 45 A.2d 289 (1945).

17. As to lower-court confusion, compare. United States v. Hoffman, 137 F.2d 416, 421 (2d Cir. 1943), with United States v. Corn, 54 F. Supp. 307, 309 (E.D. Wis. 1944), and United States v. Klee, 50 F. Supp. 679 (E.D. Wash. 1943).

18. Compare United States v. Grote, 140 F.2d 413 (2d Cir. 1944), and Gros v. United States, 136 F.2d 878, 880 (9th Cir. 1943) (indicating coercive activity necessary), with United States v. Keegan, 141 F.2d 248 (2d Cir. 1944), and Runnels v. United States, 138 F.2d 346 (9th Cir. 1943) (holding time delay sufficient). The vagueness of 
duced the notion that unlawful delay must induce particular evidence to warrant its exclusion. ${ }^{19}$ In its most recent application of McNabb, Mallory $v$. United States, the Court left no doubt that unlawful delay alone evokes exclusion. ${ }^{2 n}$ What constitutes unnecessary delay was left unsettled, however, ${ }^{21}$ and the disagreement among lower-court judges remains as great as ever. ${ }^{22}$

The muddled evolution of the $M c N a b b$ doctrine has troubled Congress as well as the judiciary. Legislative concern has centered less on the conflicting decisions of federal judges than on a fear that restricted police interrogation will impair the investigation of crime, ${ }^{23}$ for law-enforcement officials have argued that, by limiting the interrogation of arrested persons, the $M c N a b b$ rule renders many serious crimes unsolvable and thereby threatens public safety. ${ }^{24}$ Congress first reacted with a proposal-the Hobbs Bill-which was designed to overturn $M c N a b b^{25}$ and which passed the House three times but repeatedly died in committee in the Senate. ${ }^{26}$ The Mallory case revived congressional activity ${ }^{27}$ and, of the several anti-Mallory measures suggested, one

the Court's decision is noted in McCormick, Some Problems and Developments in the Admissibility of Confessions, 24 Texas L. Rev. 239, 270-71 (1946); Comment, 42 Mrce. L. REv. 679, 680 (1944); 56 HARv. L. Rev. 1008, 1009 (1943).

That unlawful delay alone was ground for exclusion should have been clear from the companion case of Anderson v. United States, 318 U.S. 350 (1943). But lower courts concentrated their attention on the more fully developed yet more ambiguous decision in $M c N a b b$, and neglected the possibilities for clarification offered by Anderson. See Note, 47 Colun. L. REv. 1214, 1217 \& nn.17 \& 18 (1947).

19. United States v. Mitchell, 322 U.S. 65,70 (1944); Upshaw v. United States, 335 U.S. 410, 413 (1948). This rationale was followed by lower courts in Alderman v. United States, 165 F.2d 622 (D.C. Cir. 1947) ; Boone v. United States, 164 F.2d 102 (D.C. Cir. 1947) ; Sykes v. United States, 143 F.2d 140 (D.C. Cir. 1944).

20. 354 U.S. 449 (1957). The Court had previously taken this position in Upshaw v. United States, supra note 19. See Orfield, Proceedings Before the Commissioner in Federal Criminal Procedure, 19 U. PITr. L. Rev. 489, 546-47 \& nn.397 \& 398 (1958).

21 . See notes 39-66 infra and accompanying text.

22. See notes $67-111$ infra and accompanying text.

23. See H.R. REP. No. 245, 79th Cong., 1st Sess. 6 (1945) ; H.R. Rep. No. 29, 80th Cong., 1st Sess. 3-4 (1947) ; S. REP. No. 1478, 85th Cong., 2d Sess. 11 (1958); H.R. REP. No. 1815, 85th Cong., 2d Sess. 5 (1958).

24. See 1944 Hearings 1-10; 1958 House Hearings 32-71; Hearngs on the Admission of Evidence (Mallory Rule) Before a Subcommittee of the Sentate Committec on the Judiciary, 85th Cong., 2d Sess. 34-42 (1958) [hereinafter cited as 1958 Senate Hearings].

25. H.R. 3690, 78th Cong., 1st Sess. (1943). This bill provided "that no failure to observe the requirement of law as to the time within which a person under arrest must be brought before a magistrate, commissioner, or court shall render inadmissible any evidence that is otherwise admissible."

26. House passage is recorded at 90 Cong. Rec. 9376 (1944); 91 Cong. Rec. 2508 (1945) ; 93 Cosa. REc. 1392 (1947). The bill was never reported out of the Senate Committee on the Judiciary. For contemporaneous reaction to the Hobbs Bill see Dession, The New Federal Rules of Criminal Procedure (pt. 1), 55 Yale L.J. 694, 710-13 (1946); 32 CoRnell L.Q. 594 (1947) ; 38 J. CRIM. L. \& C. 136 (1947).

27. Press reaction to the Mallory opinion was mixed. See U.S. News \& World Report, July 26, 1957, pp. 38-40; id., Nov. 29, 1957, pp. 34-35; Washington Post \& Times 
so far has been successful in the House. ${ }^{28}$ This bill was amended and passed by the Senate, ${ }^{29}$ but, upon emerging from conference altered still again, was killed by a point of order on the Senate floor. ${ }^{30}$

The present status of the $M c N a b b$ doctrine is unclear. Its vagueness invites unwitting violations and uneven application. Moreover, the balance which it strikes between defendants' rights and effective law enforcement seems a haphazard one. This Comment will analyze the $M c N a b b$ doctrine in the light of Mallory and subsequent lower-court decisions; question the wisdom of the Court's evidentiary rule and of proposed remedial legislation; and suggest that the difficulties arising from the doctrine's application are best remedied not by repealing it but by altering the procedural rules which underlie it.

\section{The Mallory Case and the Meaning of McNabb}

\section{The Mallory Case}

Arrested for rape at 2:30 on a weekday afternoon, Andrew Mallory was brought to police headquarters along with his two grown nephews, who were also suspects. ${ }^{31}$ In the presence of other police personnel, four officers interrogated Mallory some forty minutes. He persistently denied committing the crime. All three suspects then agreed to a lie-detector test. At 8:00 p.m., Mallory was left alone with a polygraph operator and, following an hour and a half of questioning, he admitted guilt, then repeated his confession to other officers. A deputy coroner examined him at this time and found no indications of physical or mental coercion. Subsequent to his oral confessions but before he signed a stenographic copy, the police told Mallory that he need not say or sign anything and that whatever he said could be used against him. ${ }^{32} \mathrm{He}$ was brought before a United States commissioner the following morning. The defendant was nineteen years old and incompetent to stand trial for a year following his indictment. When the case was finally tried, his signed confession was admitted in evidence over the objection of counsel. The jury convicted him and sentenced him to death.

On appeal, Mallory claimed that his confession should have been excluded from evidence because it was procured in violation of rule $5(\mathrm{a}) .^{33}$ Rejecting this contention, the court held it reasonable and within the rule for the police to delay arraignment until fairly certain that the guilty party had been apprehended. The court said that, since the accused was one of three suspects, the

Herald, June 27, 1957, p. 1, col. 2; id., June 30, 1957, p. E5, col. 3; id., July 5, 1957, p. A15, col. 1; New Republic, April 7, 1958, p. 3.

28. See notes 177-78 infra and accompanying text.

29. See notes $179-86$ infra and accompanying text.

30. See notes 187-92 infra and accompanying text.

31. Mallory v. United States, 354 U.S. 449-50 (1957). Except as otherwise indicated, the statement of facts appearing in text was drawn from id. at 450-51, 455 .

32. 1958 House Hearings 37; 1958 Senate Hearings 41. This procedure was not discussed by either the court of appeals or the Supreme Court.

33. Mallory v. United States, 236 F.2d 701, 703 (D.C. Cir. 1956). 
police could postpone arraigning him for a reasonable time until able to justify charges. ${ }^{34}$ Furthermore, the court observed, the accused did not show that the interval complained of induced his confession. ${ }^{35}$ Judge Bazelon dissented and noted an injustice in permitting arrest and interrogation to occur for the purpose of establishing "probable cause"-which should have existed before the arrest was made. ${ }^{36}$ The dissent challenged the court's intimation that a delay which did not induce a confession would not result in exclusion. According to Judge Bazelon, a delay for purposes of interrogation is illegal ;7 and, if delay was unavoidable or reasonable as the majority suggested, the police could introduce a confession obtained through interrogation only if, before questioning began, they had advised the accused of his right to remain silent. $^{38}$

34. Ibid. In United States v. Carignan, 342 U.S. 36 (1951), the Supreme Court implied in dictum that arraignment may be lawfully delayed for the purpose of questioning an arrested person in order to ascertain his guilt. See id. at 44 . But this dictum was diametrically opposed to the Court's reasoning in Upshaw v. United States, 335 U.S. 410 (1948), decided but three years earlier. The Carignan opinion was written by Justice Reed, who had dissented in $M c N a b b, 318$ U.S. at 349 ("I am opposed to broadening the possibilities of defendants escaping punishment by these more rigorous technical requirements in the administration of justice.") ; had concurred in United States v. Mitchell, 322 U.S. 65, 71 (1944) ("[T]he $M c N a b b$ rule is that where there has been illegal detention ... joined with other circumstances ... contrary to proper conduct of federal prosecutions, the confession will not be admitted. . . . However, . . I do not agree that the rule works a wise change in federal procedure."); and dissented in Upshaw, supra at 429 ("This [ $M c N a b b]$ rule is that purposeful, unlawful detention illegally to extract evidence and the successful extraction of confessions under psychological pressure, other than mere detention for limited periods, makes confessions so obtained inadmissible.").

35. 236 F.2d at 703 ; see note 1.9 supra.

36. 236 F.2d 706-07.

37. Id. at 707. Compare Upshaw v. United States, 335 U.S. 410, 413 (1948).

38. $236 \mathrm{~F} .2 \mathrm{~d}$ at 705 . In developing the $M c N a b b$ rule, the Supreme Court had paid little attention to the accused's lack of counsel, or to the failure of the police to inform him prior to questioning of his right to remain silent. See McNabb v. United States, 318 U.S. 332, 336 (1943) ; McNabb v. United States, 123 F.2d 848, 851-52 (6th Cir. 1941). No mention of a warning was made in United States v. Mitchell, 322 U.S. 65 (1944), or in Upshaw v. United States, supra note 37. But see Brief for Petitioner, p. 4, United States v. Mitchell, supra (officers testified that they told the accused "that he did not have to say anything") ; Record, p. 83, Upshaw v. United States, sutpra note 37 (warning that accused need not make a statement and that any statement made could be used against him written above signed confession). Yet, in Carignan v. United States, 342 U.S. 36 (1951), the Court noted that the purpose of $M C N a b b$ was to abolish the opportunity for police pressure before the accused had the benefit of appearing before a committing officer and being advised of his rights. Id. at 44-45. See note 2 supra.

Lower-court judges, in applying the $M c N a b b$ rule prior to Mallory, not only took notice of police cautioning but in addition considered such factors as the accessibility of committing officers and the susceptibility of a particular defendant to psychological pressure. See Pixley v. United States, 220 F.2d 912, 913 (10th Cir. 1955) (caution); Haines v. United States, 188 F.2d 546, 550 (9th Cir. 1951) (caution); Duncan v. United States, 197 F.2d 935, 937 (5th Cir.), cert. denied, 344 U.S. 885 (1952) (accessibility); Garner v. United States, 174 F.2d 499, 501-02 (D.C. Cir.), cert. denied, 337 U.S. 945 (1949) (accessibility); Watson v. United States, 234 F.2d 42, 48 (D.C. Cir. 1956) (susceptibil- 
Reaching the result advocated by Judge Bazelon, the Supreme Court reversed Mallory's conviction. ${ }^{80}$ The Court left no doubt that "unnecessary delay" requires the exclusion of evidence even when the delay does not cause or induce the accused to speak. But the Court failed to define how long delay may last before detention becomes "unnecessary." Certain sections of the opinion indicate that the permissible interval between arrest and arraignment is extremely short: the accused must be taken before a judicial officer "as quickly as possible"; 40 the Rules of Criminal Procedure contemplate "little more leeway than the interval between arrest and the ordinary administrative steps required to bring a suspect before the nearest available magistrate." 41 Still, the Court expressly permitted the police time to "book" an arrested person, and observed that sometimes "circumstances may justify a brief delay."42 Nonetheless, it ruled that in no event may arraignment be postponed "to carry out a process of inquiry that lends itself, even if not so designed," to eliciting incriminating statements, ${ }^{43}$ and that delay may not be of a nature to "give opportunity for the extraction of a confession." 4

These generalities leave many of the $M c N a b b$ interstices unfilled. ${ }^{45}$ The only "circumstance" which the Court mentions as justifying delay is the "quick verification" of an accused's story by third parties. ${ }^{46}$ Although a list of other such "circumstances" could not be considered as exhaustive, the mention of one without an explanation of why it justifies delay is perplexing. If the Court had described several, a useful definition might be inferrable. The Court was scarcely more explicit about the duration of "brief delay": it must not be "of a nature to give opportunity for the extraction of a confession." 47 If, in using this phrase, the Court contemplated the use of physical brutality, permissible delay would of necessity be momentary, for a confession can be extracted by torture in a matter of minutes. But the Court itself acknowledged that rule 5(a) "does not call for mechanical or automatic obedience."48 Possibly, the Court meant to keep opportunities for physical coercion to a minimum. More probably, Mallory's concern over extracted confessions related back to the sentence in the decision forbidding a "process of inquiry"-that is, presumably, a period of interrogation inviting psychological pressure. Read

ity) ; Rettig v. United States, 239 F.2d 916, 927 (D.C. Cir. 1956) (concurring opinion) (susceptibility). See also Note, 43 VA. L. REv. 915, 920-30 (1957).

39. 354 U.S. 449 (1957).

40. Id. at 454 .

41. Id. at 453 .

42. Id. at 454-55. Booking includes "making the necessary papers," fingerprinting and identification. See 1958 Senate Hearings 407; NEw YoRk CITY Pólice Dep't, RULES AND Procedures ch. 9 (1956) (procedure at station house after arrest).

43. 354 U.S. at 454.

44. Id. at 455 .

45. But see 60 W. VA. L. REv. 195, 196 (1958) ("Mr. Justice Frankfurter has written a clear and lucid manual on the law of arrest and detention for federal officers."). 46. 354 U.S. at 455.

47. Ibid.

48. Ibid. 
in this manner, Mallory defines unlawful delay to effectuate the $M c N a b b$ objective of preventing the coercion likely to result from rigorous questioning. ${ }^{49}$ The Court could have defined the duration of unlawful delay more precisely by spelling out the indicia of a "process of inquiry." As matters stand, lower courts applying Mallory are left to determine whether the duration of inquiry alone is decisive or whether other factors such as the number and rapidity of questions and the suggestibility of the accused must also be considered.

After laying down general principles, the Mallory Court asserted that the "circumstances of this case preclude a holding that arraignment was without "unnecessary delay." "50 The Court then mentioned that the accused was questioned "even though the police had ample evidence from other sources than the petitioner for regarding the petitioner as the chief suspect." this fact is confusing. It suggests that the questioning would have been less objectionable had the police lacked evidence of guilt. But the opinion elsewhere prohibits "a process of inquiry that lends itself . . . to eliciting damaging statements to support the arrest,"52 and disapproves arrests made without "probable cause" in order to extract information to justify charges. ${ }^{53}$

The Court also noted that Mallory was of extremely limited intelligence and unadvised of his right to counsel..$^{54} \mathrm{He}$ was not told prior to interrogation that he need not answer any questions and that anything he said could be used against him. ${ }^{55}$ The Court's allusion to these facts may well relate back to its prohibition of any delay which would permit a period of interrogation likely to result in psychological coercion. Such a relation back is supportable, since the probability of coercion is lessened when the accused is mentally alert and properly forewarned of his rights. ${ }^{56}$ His intelligence bears not only upon his general ability to resist coercion ${ }^{57}$ but also upon the sufficiency of a police caution, for a warning is of no relevance unless the accused can understand it.58 And if he is of limited intelligence, a warning, to be meaningful, would have to be carefully explained to him. ${ }^{50}$

\footnotetext{
49. See note 15 supra.

50. 354 U.S. at 455.

51. Ibid.

52. Id. at 454 .

53. Id. at 456 .

54. Id. at 455 ; see note 38 supro.

55. Ibid.; see notes 32,38 supra.

56. See Green v. United States, 236 F.2d 708, 715, 717 (D.C. Cir. 1956) (dissenting opinion), reo'd on other grounds, 355 U.S. 184 (1957); Note, 43 VA. L. REv. 915, 928 (1957). Compare Fikes v. Alabama, 352 U.S. 191 (1957), 6 DE PAUL L. Rev. 293, 295.

57. Compare Fikes v. Alabama, supra note 56; Stein v. New York, 346 U.S. 156, 185 (1953) ; 18 U. Pitr. L. Rev. 823 (1957).

58. In United States v. Valente, 155 F. Supp. 577 (D. Mass. 1957), the court accorded no weight to a warning given prior to interrogation to an accused who spoke broken English and was questioned through an interpreter.
}

59. Cf. Walker v. Johnston, 312 U.S. 275 (1941); Evans v. Rives, 126 F.2d 633 (D.C. Cir. 1942) ; Bayless v. Johnston, 48 F. Supp. 758 (N.D. Cal. 1943). 
On the other hand, the Court's discussion of Mallory's individual characteristics may only have been intended to demonstrate the importance of applying a strict but uniform standard in his case. Rule 5(a), in speaking of "unnecessary delay," appears to refer exclusively to the general feasibility of prompt arraignment and not at all to the peculiarities of each particular defendant. ${ }^{00}$ By particularizing on Mallory's susceptibility to questioning, the Court implied the contrary-but without specifying the weight, if any, to be given the special characteristics of the accused.

The principal defect of the Mallory opinion was its failure to delineate clearly the relevance of the accessibility of committing magistrates. Among the "circumstances" which the Court enumerated as precluding a holding that the arraignment was "without unnecessary delay," was the fact that arraignment could have easily been accomplished. ${ }^{61}$ The arrest, the Court noted, was made "within the vicinity of numerous committing magistrates," and arraignment could have taken place in the very building in which the prisoner was being held. ${ }^{62}$ Furthermore, in its more general discussion, the Court indicated that the pertinent delay is the time consumed in bringing the suspect before the "nearest available magistrate." 63 Thus, the opinion strongly suggests that delay is legitimate when caused by the inaccessibility of a committing officer. ${ }^{04}$ If this is so, Mallory authorizes delays much longer than might be needed to "extract a confession" or to conduct a "process of inquiry" toward that end. Yet the need to protect arrested persons against potentially coercive activity represents the Court's principal justification of its exclusionary rule. ${ }^{65}$ Inconsistent considerations have therefore been advanced without any indication as to which shall govern when they conflict. A possible reconciliation could be effected if those delays necessitated by the unavailability of a magistrate were allowed, but interim conduct constituting a process of inquiry or the extraction of a confession were proscribed. ${ }^{66}$ As written, however, Mallory offers no such reconciliation. The Court's silence has left to lower tribunals the formulation of a solution which may or may not meet with the Court's approval.

\section{Lower-Court Decisions Since Mallory}

The burden of interpreting the Mallory decision has fallen principally upon the Court of Appeals for the District of Columbia, which hears the great

60. See note 1 supra.

61. 354 U.S. at 455 .

62. Ibid.

63. Id. at 453. Prior to Mallory, lower courts frequently held $M c N a b b$ inapplicable when a committing officer was unavailable. See note 38 supra.

64. See Orfield, Proceedings Before the Commissioner in Federal Criminal Procedure, 19 U. PITT. L. KEv. 489, 556 (1958); Note, 43 VA. L. Rev. 915, 924 (1957). But see 26 Geo. Wase. L. Rev. 102, 105 (1957).

65. See note 15 stipra.

66. See Judge Bazelon's dissent in Trilling v. United States, Nos. 13069, 13165, and 13212, D.C. Cir., April 17, 1958, at 22-23. 
majority of federal criminal appeals. ${ }^{67}$ In determining the legality or illegality of delay under rule 5(a), this court has concentrated its attention upon police purpose, justifying circumstances, the accessibility of committing officers, and the maximum time permitted the police regardless of the individual situation. In nearly every case, a combination of these elements has been present; hence, it is difficult to determine the weight which the court attaches to any one of them.

\section{The Watson and Carter Cases}

Two cases decided shortly after Mallory seem to place crucial emphasis on the purpose for which arraignment was delayed. In Watson $v$. United States. the District of Columbia Circuit held a delay of eighteen hours unlawful because it was designed to obtain incriminating statements through interrogation. ${ }^{68} \mathrm{~A}$ confession secured under similar circumstances in Carter $v$. United States was also held inadmissible; the accused had been detained fifteen hours through a night of continual questioning, presumably for the purpose held illegal in Watson. ${ }^{69}$ In both instances, the police had failed to notify the accused of his rights before questioning him..$^{70}$ And, in Watson, the absence of a proper warning seems to have influenced the finding of an illicit police motive. ${ }^{71}$ But Carter and $W^{7}$ atson did not dispel the uncertainty generated by Mallory as to warning: a subsequent District of Columbia case considered a suitable warning as one of several factors validating a confession $;^{72}$ and still another case indicated in a footnote that the failure to caution was harmless error. ${ }^{73}$ To date, the legal effect of a preinterrogation warning remains largely unexplained.

A more puzzling aspect of the Carter and Watson opinions is the lack of discussion concerning the inaccessibility of committing officers. In both cases, the arrests occurred after the usual working hours of a magistrate, and the incriminating statements were obtained during the early hours of the morn-

67. See 1958 Senate Hearings 25-27. The Mallory doctrine has been applied in a number of district court decisions. See $i d$. at 93-101.

68. 249 F.2d 106 (D.C. Cir. 1957).

69. 252 F.2d 608, 613-14 (D.C. Cir. 1957).

70. Watson received no caution at all. 249 F.2d at 109. Carter was warned that he need not speak only after he had orally confessed-the advice being inserted in the first paragraph of his written confession. $252 \mathrm{~F} .2 \mathrm{~d}$ at 619 . The practice of warning an accused of his rights prior to his signing a written statement but after interrogation seems prevalent among police. See 1958 Honse Hearings 37, 61; 1958 Senate Hearings 42; text at note 32 supra. On the existence of any police warning whatsoever, see Letters from Law Enforcement Officials to the Stanford Law Review, Nov. \& Dec. 1952. The Mallory decision may change police practice, however. See 1958 Senate Hearings 42, 398.

71. $249 \mathrm{~F} .2 \mathrm{~d}$ at 109.

72. Milton Mallory v. United States, No. 14023, D.C. Cir., March 31, 1958, at 4.

73. Trilling v. United States, Nos. 13069, 13165, and 13212, D.C. Cir., April 17, 1958 , at 14 n.15. 
ing. ${ }^{74}$ Though Mallory implies that delay may be "necessary" when committing officers are unavailable, Watson and Carter went off on other grounds. Likewise, in Starr $v$. United States-in which the defendant had been arrested at 1:00 a.m. and confessed seven to nine hours later-the accessibility issue was disregarded. ${ }^{75}$ The court simply stated that Mallory required exclusion. Subsequent cases indicate, however, that the inaccessibility of committing officers legalizes delay and postpones application of the $M c N a b b$ rule. ${ }^{76}$ Even if these later cases did not demonstrate that Watson, Carter, and Starr had all invalidated confessions unnecessarily, Porter $v$. United States-in which the accused had been arrested at 10:30 p.m. and had confessed about threequarters of an hour later-clearly held that unnecessary delay could occur only during the usual professional hours of committing officers. ${ }^{77}$

\section{The Metoyer and Milton Mallory Cases}

A later pair of cases focused on those "circumstances" which may justify a brief delay. In Metoyer $v$. United States, the court, by a 2-1 vote, countenanced a three-and-a-half hour detention which served principally to allow the transcription of the accused's oral confession; he had voluntarily offered the confession when the District of Columbia police confronted him. ${ }^{78}$ The majority, holding both the oral and written confessions admissible, reasoned that the Mallory opinion permits sufficient time to prepare a confession for signature. ${ }^{79}$ Furthermore, the majority said, "every citizen has a right to insist that the police make some... definitive inquiry before" the "stigma" of arraignment attaches. ${ }^{80}$ The latter statement apparently overlooked the "stigma" of arrest, and minimized the danger of police misconduct.

74. In Watson, the accused had made various oral admissions between $3: 15$ and 9:00 a.m. After 9:00 a.m., when committing officers became available, he re-enacted the crime and consented to a search of his apartment which yielded some articles of clothing. The court held all three types of evidence inadmissible. 249 F.2d at 109. Carter, arrested at $8: 30$ p.m., had confessed in writing by 7:30 a.m. and was arraigned at noon. $252 \mathrm{~F} .2 \mathrm{~d}$ at 614 .

75. No. 13865, D.C. Cir., Feb. 13, 1958.

76. See Milton Mallory v. United States, No. 14023, D.C. Cir., March 31, 1958, at 3-4; Trilling v. United States, Nos. 13069, 13165, and 13212, D.C. Cir., April 17, 1958, at 9-10.

77. 258 F.2d 685, 692 (D.C. Cir. 1958). Later admissions by the accused were not considered exculpatory statements. $I d$. at 692-93; see note 10 supra.

Judge Bazelon, in dissent, asserted that a committing officer is always available in the District of Columbia. 258 F.2d at 695. See also Garner v. United States, 174 F.2d 499, 504 (D.C. Cir. 1949) (dissenting opinion), cert. denied, 337 U.S. 945 (1949); Akowskey v. United States, 158 F.2d 649, 650 (D.C. Cir. 1946).

78. 250 F.2d 30 (D.C. Cir. 1957).

79. Id. at 32-33.

80. It. at 33. The "stigma" argument has also been used by law-enforcement officials seeking legislative overruling of $M c N a b b$. 1944 Hearings 46 . See also 1958 House Hearin!s 2; 19.58 Scnate Hearings 35 (Mallory Rule). 
Chief Judge Edgerton, dissenting, agreed that the oral confession was admissible, but felt that the written confession-made after a delay motivated by "the desire of the police" to obtain it-should have been excluded. ${ }^{\mathbf{}}$

In the other of these two cases, Milton Mallory $v$. United States, the accused (a nephew of the Mallory who prevailed in the Supreme Court), ${ }^{82}$ was arrested while intoxicated at 8:00 in the evening, and jailed.83 In the meantime, hospital tests were conducted on the victim to confirm the alleged offense of carnal knowledge. The next morning, after ten minutes of questioning, the accused admitted the crime. He then was warned of his right to remain silent and the possible effects of any statement he made. He signed a written confession and was arraigned at noon. The majority, noting that the accused was warned of his rights before he signed a statement, held the delay justified by the defendant's drunken condition, the late hour of arrest, and the need to verify the victim's story. ${ }^{84}$ Judge Bazelon argued in dissent that, even if some delay were permissible pending examination of the complainant, since verification had been completed during the night, the interval which ensued on the morning after arrest was illegal because intended to permit interrogation. ${ }^{85}$ Judge Bazelon further asserted that the late hour of arrest did not justify the delay inasmuch as the Government had conceded the accessibility of a committing officer, ${ }^{86}$ and that if drunkenness may delay arraignment, no interrogation should be allowed until the accused is sufficiently sober to appear before a magistrate. ${ }^{87}$

\section{Trilling v. United States}

The first examination of the Mallory doctrine by the District of Columbia Circuit en banc occurred in Trilling $v$. United States, and resulted in three conflicting opinions. ${ }^{88}$ Trilling was arrested at 5:30 a.m. on a charge of burglarizing a warehouse. At the time of arrest, the police had sufficient evidence to constitute "probable cause" if not to establish the accused's guilt beyond a reasonable doubt. After talking for about forty-five minutes with a police sergeant who was a family friend, Trilling admitted burglarizing the warehouse. He was then further detained and interrogated about other crimes still unsolved by the police. Throughout the day, he made various oral admissions and confessions and, toward 4:00 in the afternoon, one of the confessions was put in writing and signed. Trilling was subsequently arraigned on the

81. $250 \mathrm{~F} .2 \mathrm{~d}$ at 33-34.

82. 1958 Senate Hearings 6.

83. Milton Mallory v. United States, No. 14023, D.C. Cir., March 31, 1958.

84. Id. at 4.

85. Id. at $7-8$.

86. Id. at 7; see note 77 supra.

87. Milton Mallory v. United States, supra note 83, at 8-9. See also Porter v. United States, 258 F.2d 685, 693, 696 n.4 (D.C. Cir. 1958) (dissenting opinion).

88. Nos. 13069, 13165, and 13212, D.C. Cir., April 17, 1958. The statement of facts appearing in text is drawn from the court's opinion. 
basis of this confession. Even after arraignment, interrogation continued and more incriminating statements were taken until 10:30 in the evening. Judge Danaher, reluctantly joined by Judge Burger, held the confession of the warehouse burglary admissible, but excluded all others. Judges Bazelon, Edgerton, Fahy, and Washington were of the opinion that no statement obtained from the accused was admissible; and Judges Bastian, Miller, and Prettyman voted to admit all the evidence. The split in the court was such that Judge Danaher's conclusions received majority support.

Judge Danaher gave a strange twist to the Watson rationale that a delay is illegal if its purpose is to obtain incriminating statements legitimizing an arrest or establishing guilt..$^{89} \mathrm{He}$ apparently drew the negative inference that, if a confession is not necessary to justify an arrest or to prove guilt, a delay could not be illicitly motivated and therefore would not violate rule 5 (a) ${ }^{90}$ Since Trilling, at the time of his first confession, was not being detained in order to extract statements from him or to subject him to a process of inquiry, Judge Danaher ruled that the initial confession was admissible. ${ }^{91}$ But, the judge continued, after Trilling had made this confession, delay became unlawful because the police had no evidence implicating him in crimes other than the warehouse burglary..$^{92}$ The purpose of delay being to obtain incriminating statements to justify arrest and support guilt for these other crimes, the subsequent confessions were held inadmissible.

Abstracted into a rule of law, the Danaher opinion would admit any evidence challenged under Mallory' provided the evidence, when obtained, is not needed to establish guilt. So read, the opinion will not affect the outcome of any case. Unlike the wrongful admission of coerced confessions, the inclusion of evidence elicited in violation of rule 5 (a) does not in itself constitute reversible error. ${ }^{93}$ And misapplication of the $M c N a b b$-Mallory doctrine does not merit overturning a conviction if the evidence erroneously admitted is not needed to establish the defendant's guilt. ${ }^{94}$ Judge Danaher thus concerned himself with a question of admissibility which seems immaterial at the appellate level.

89. See id. at $14 \&$ n.15.

90. Id. at 9. See also United States v. Simpson, 162 F. Supp. 677 (D.D.C. 1958).

91. Trilling v. United States, supra note $S \&$, at 10.

92. Id. at 11-15.

93. Id. at 11 n.10; Porter v. United States, 258 F.2d 685, 692-93 (D.C. Cir. 1958). But see Trilling v. United States, supra at 33 (dissenting opinion).

Prior to Stein v. New York, 346 U.S. 156 (1953), the Supreme Court had indicated that the admission into evidence of a confession obtained in violation of due process of law would invalidate a conviction regardless of the sufficiency of evidence without the confession. Haley v. Ohio, 332 U.S. 596 (1948); Malinski v. New York, 324 U.S. 401 (1945). Stcin implied that if sufficient evidence existed in the absence of a coerced confession, a conviction would stand. 346 U.S. at 188-92. Payne v. Arkansas, 356 U.S. 560, 568 \& n.15 (1958), 21 GA. B.J. 116, did not follow this Stein dictum, however.

94. See note 93 supra; FEn. R. CRIM. P. 52(a); Kotteakos v. United States, 328 U.S. 750, 764-65 (1946) ; Haines v. United States, 188 F.2d 546, 550 (9th Cir.) (dictum), cert. denied, 342 U.S. 888 (1951). 
Judge Prettyman, joined by Judges Bastian and Miller, read Mallory more as forbidding coercive interrogation than as compelling prompt arraignment. He stated that the interrogation leading to Trilling's initial confession did not contain the elements of coercion supposedly deemed intolerable in Mallory. ${ }^{95}$ And, since the police are not required to arraign prior to normal business hours, he concluded that the delay during which the first confession was obtained was reasonable and therefore lawful under rule $5(\mathrm{a}) .^{96}$ Turning to the confessions of and admissions concerning other crimes, Judge Prettyman found them admissible by categorizing Trilling as a "suspect" not under arrest for those offenses at the time he was questioned about them. ${ }^{97}$ The judge reasoned that rule 5(a) applies only to "arrested persons," and that the police may interrogate a suspect as long as the questioning is "reasonable-for-thepurposes-of-information."98 This standard, he declared, was met.

Judge Prettyman's view of unlawful delay as just another factor going to the voluntariness of a confession seems inconsistent with the $M c N a b b$ rule. The Supreme Court has indicated that the exclusion of evidence under $M c$ $N a b b$ does not in any way depend upon proof of coercion, ${ }^{99}$ and that a violation of rule 5 (a) need not be a violation of due process. ${ }^{100}$ More ominously, Judge Prettyman would incorporate into rule 5(a) a novel distinction between "suspect" and "arrested person." The distinction suggests that arrest occurs at some point after the police have taken an individual into custody and questioned him. Historically, however, any taking into custody to secure the administration of justice has constituted an arrest; $;^{101}$ and a prior period of detention for interrogation is unknown to federal law and is permissible in but a small minority of state jurisdictions. ${ }^{102}$ Indeed, were prearrest deten-

95. See Trilling v. United States, supra note 88 , at 59.

96. Id. at 59-60.

97. See $i d$. at 61 .

98. See $i d$. at $48-49$; see note 1 sipra.

99. United States v. Mitchell, 322 U.S. 65, 68 (1944); Note, 66 Y YLE L.J. 270, 278 n.33 (1956) (defendants seldom able to show coercion).

100. McNabb v. United States, 318 U.S. 332, 340 (1943); see Gallegos v. Nebraska, 342 U.S. 55, 64 (1951); Watts v. Indiana, 338 U.S. 49, 50 n.1 (1949).

101. 1 Alexander, Arrest 353-54 (1949); Dax \& Tibbs, Arrest, Search anu Seizure 6 (1946) ; Perkins, The Law of Arrest, 25 Iowa L. Rev. 201 (1940). Arrest includes detention by the police. 22 Ops. ATT'Y GeN. 51 (1898); Waite, The Law of Arrest, 24 Texas L. Rev. 279, 296-97 (1946) ; Note, 100 U. PA. L. Rev. 1182, 1185-88 (1952). For a general treatment of arrests under federal law, see Orfield, Warrant of Arrest and Summons Upon Complaint in Federal Criminal Procedure, 27 U. Cinc. L. Rev. 1 (1958). Compare Royal Commission on Police Powers and Procedure, Report, Casd. No. 3297, at 55-59 (1929) (arrest and detention in England).

102. For the minority jurisdictions, see DEL. CODE ANN. tit. 11, § 1901-02 (1953); Mass. Ann. Laws ch. 41, \& 98 (1952) ; N.H. Rev. Stat. ANn. $\$ 594: 2$ (1955) ; R.I. GEN. LAws ANn. \& 12-7-1 (1957). These laws are all similar to Uniform Arrest Act $\$ 2$ which allows the detention of certain persons for a period not to exceed two hours. See Warner, The Uniform Arrest Act, 28 VA. L. Rev. 315, 320-24 (1942). See generally Foote, Safeguards in the Law of Arrest, 52 Nw. U.L. REv. 16 (1957). 
tion permitted, the protection afforded by $M c N a b b$ would be slight, for the police could delay arrest until after interrogation. And Judge Prettyman would merely require that prearrest questioning be "reasonable-for-the-purposes-of-information."

To Judge Bazelon, with whom Chief Judge Edgerton concurred, Mallory meant that all confessions elicited through questions put to an arrested person before his arraignment must be excluded, ${ }^{103}$ and that all of Trilling's statements were therefore inadmissible. The judge termed the hour of arrest irrelevant, because a committing officer is always available within the District of Columbia. ${ }^{104}$ Furthermore, he stated, if delay does become necessary, the police may not use the interval to acquire incriminating evidence by questioning the prisoner. ${ }^{105}$ Nor will a proper preinterrogation cautioning of the defendant as to his rights render his answers admissible, since the law reserves that function to the magistrate and not the police. ${ }^{106}$ This last assertion finds apparent support in the $M c N a b b$ dictum that the power of the criminal law is too awful to leave in the possession of the police alone. ${ }^{107}$

In seeking to prohibit all interrogation prior to arraignment, Judge Bazelon departs markedly from prior case law. His attempt to protect defendants against questioning occasioned by necessary delays may represent a desirable policy; but every decision from $M c N a b b$ through Mallory geared the admissibility of evidence to violations of prompt-arraignment legislation. Those cases impose no limit on interrogation so long as rule $5(a)$ is complied with.

\section{Heideman v. United States}

Heideman $v$. United States at last presented the court with the sharp issue of how much interrogation is permissible in the absence of collateral considerations. ${ }^{108}$ There, the accused had been questioned for fifteen minutes and then had given a full confession. He was arraigned approximately an hour after arrest-a delay, according to the court, no longer than that essential to complete ordinary administrative procedures. The court held that the brief period of questioning had been sufficiently curtailed to be lawful, that, indeed, the evidence affirmatively showed nothing more than an appropriate inquiry to ensure that the accused was properly charged. ${ }^{109}$ To support this conclusion, the court outlined the extent of a proper inquiry: the police may ask the accused what he knows about the crime; they may reveal the evidence which they have already gathered and ask him if he wishes to comment upon it ; they may ask him if he has anything further to say. ${ }^{110}$ In the court's view,

103. Trilling v. United States, supra note 88 , at 18 .

104. Id. at 20; see note 77 supra.

105. Trilling v. United States, supra note 88 , at 22-23.

106. Id. at 27 n.13.

107. MIcNabb v. United States, 318 U.S. 332, 343 (1943).

108. No. 14414, D.C. Cir., Sept. 25, 1958.

109. Id. at 4 .

1.10. Id. at 5 . 
questioning becomes unlawful only when it constitutes "grilling" or continues beyond the brief period allowable for routine administrative action. ${ }^{111}$ While the term "grilling" is equally as vague as "process of inquiry," Heideman's enumeration of permissible questions affords more certainty than did the language in Mallory. At least, when committing officers are readily available and when no justifying "circumstances" are present, Heideman provides comparatively definite standards by which the police may act.

\section{Summary}

The efforts of the District of Columbia appellate court, examined together, do not dispel the confusion which surrounds the Mallory opinion. Although Watson and Carter indicate otherwise, the inaccessibility of committing officers apparently serves to toll the operation of $M c N a b b$. Still unclear is whether the police can legalize an interrogation by advising the accused that he may retain counsel or that anything he says may be used against him. While a start has been made toward detailing the "circumstances" justifying delay, the list-which now includes drunkenness, identification of the arrested person, transcription of an oral confession, and verification of the accused's or victim's story-is necessarily incomplete. Determining the delay which particular "circumstances" may warrant is also fraught with difficulty. Heideman alone addresses the problem of an interrogation's permissible length and sets standards enabling the police to ascertain the legality of their conduct. But its particular fact situation-divorced from the accessibility problem, from justifying "circumstances," and from the effect of a proper police warningprecludes a substantial contribution to predictability.

\section{Arguments Against the McNabb Doctrine: An Analysis}

\section{The Argument}

\section{Interrogation as a Source of Confessions}

The $M c N a b b$ rule has been under constant fire from law-enforcement officers since its formulation. ${ }^{112}$ The congressional hearings provoked by $M c N a b b$ and by Mallory are filled with vigorous official complaints that the police and other investigating agencies will be deprived of an opportunity to interrogate arrested persons thoroughly and, as a result, will be unable to secure sufficient evidence to convict the perpetrators of many serious crimes. ${ }^{113}$ Confessions,

111. Ibid.

112. E.g., Statement of Joseph T. Votava, United States Attorney for the District of Nebraska, 1 Comments, Recommendations and Suggestions Recerved Concerning the Preinminary Draft of the Federal Rules of Criminal Procedure 39 (1943) [hereinafter cited as Comments]; Inbau, The Confession Dilemma in the United States Supreme Court, 43 InL. L. REv. 442 (1948); Wickersham, The Supreme Court and Federal Criminal Procedure, 44 CORNELL L.Q. 14, 22-23 (1958).

113. 1944 Hearings 1-10, 27-60; 1958 House Hearings 2-21, 32-101; 1958 Senate Hearings $3-12,22-45$. 
the argument runs, are the most important source of criminal convictions : the vast majority of successful prosecutions follow pleas of guilty which in turn are preceded by confessions or damaging admissions. ${ }^{114}$ And, in contested cases, a confession is of course most telling evidence against the accused. Furthermore, it is claimed, incriminating statements are rarely obtained without prior interrogation ; 115 besides, questioning produces more information and evidence than any other investigative activity ${ }^{116}$ and is particularly essential when a skilled criminal is accused, for, having probably acted in the absence of witnesses, he alone can divulge the truth. ${ }^{117}$

\section{Commentary}

The importance of interrogation seems incontestable. ${ }^{118}$ Incriminating statements, even if not always indispensable to an effective prosecution, are valuable evidence which should not be frivolously excluded. ${ }^{119}$ On the other hand, the powerful impact of such statements-especially of confessions-on a trier of facts dictates that courts scrutinize them closely for trustworthiness before admitting them into evidence. ${ }^{120}$ Moreover, the value of incriminating evidence to the prosecution may tempt overzealous police to indulge in brutal or shocking extractive methods. ${ }^{121}$ "Due process" therefore requires that an accused's statement, to be admissible, have been elicited under circumstances which neither impeach its reliability nor suggest outrageous police conduct. ${ }^{122}$

Opponents of $M c N a b b$ do not espouse a change in constitutional doctrine. They simply insist that the police be allowed to undertake noncoercive inquiries leading to the acquisition of reliable evidence. ${ }^{123}$ In other words, they would permit any method of questioning permissible under the Constitution.

114. Statement of J. Edgar Hoover, 1 Comments 32. Compare Inbau, supra note 112, at 447; Note, 28 IND. L.J. 374, 388 (1953).

115. See Mulbar, Interrogation 33 (1951) [hereinafter cited as Mulbar]; 1958 House Hearings 36; 1958 Senate Hearings 70.

116. Mulbar 3; see Kidd, Police Interrogation 13-14 (1940) [hereinafter cited as Krnd]; Day, An Instructional Approach to Criminal Interrogation, Police, May-June 1958, p. 47.

117. 1958 House Hearings 33 (Statement of Robent V. Murray, Chief of Police, Metropolitan Police Dep't, Washington, D.C.); see Note, 60 YALE L.J. 1228 n.2 (1951).

118. See S. Rep. No. 1478, 85th Cong., 2d Sess. 11 (1958).

119. See 3 Wigmore, EVIDENCE $\S 866$ (3d ed. 1940); Coe, Practices of Police and Prosecution Prior to Trial, 17 LAw. GuILd REv. 62, 63-64 (1957).

120. See 3 WigMore, Evidence $\S 822$ (3d ed. 1940); MÜNSTERBERG, ON THE WiTNESS STAND 143-44 (1949).

121. See, e.g., Williams v. United States, 341 U.S. 97 (1951) ; Brown v. Mississippi, 297 U.S. 278 (1936) ; Ziang Sung Wan v. United States, 266 U.S. 1 (1924).

122. Paulsen, The Fourteenth Amendment and the Third Degree, 6 STAN. L. REv. 411 (1954) (collecting authorities); see note 15 supra. The same test apparently applies both to admissions and confessions. See Ashcraft v. Tennessee, 327 U.S. 274, 278 (1946); Wilson v. United States, 162 U.S. 613, 621 (1896); Comment, 4 KaN. L. Rev. 108 (1955). But see Stein v. New York, 346 U.S. 156, 162 n.5 (1953).

123. See Inbau \& Reid, Lie Detection and Criminal Interrogation 195-97 (3d ed. 1943) [hereinafter cited as INBAU \& REID]; 1958 Senate Hearings 35; Inbau, The 
If the fruits of police interrogation are deemed admissible whenever no constitutional violation can be shown, the accused may be inadequately protected. In the face of police testimony stoutly denying any irregularity, a defendant is often unable to prove a constitutional violation when one in fact exists. ${ }^{124}$ Evidence of mental coercion may be especially elusive. A court, in weighing the constitutionality of admitting an allegedly coerced confession, must measure the effect of police methods upon the individual defendant. ${ }^{12 \pi}$ True, varying periods of interrogation have been held unconstitutional depending upon such demonstrable facts as the education, intelligence, and general background of the accused. ${ }^{126}$ But allegations of momentary tensions or underlying psychological deviations which might aggravate the suggestiveness of interrogation are difficult to substantiate. ${ }^{127}$ Thus, to avoid saddling the accused with an unconscionable evidentiary burden, a rule more rigid than the "due process" ban on protracted interrogation seems necessary.

The need for a strict rule is heightened by the fact that law-enforcement authorities, crowding the edges of "due process," have developed elaborate and refined methods of interrogation designed to obtain as many "voluntary" self-incriminating statements as possible. While eschewing coercion, the police place an accused at a carefully calculated psychological disadvantage. He is taken from the reassuring atmosphere of his home and its reminders of his individual rights. ${ }^{128} \mathrm{He}$ is questioned with a minimum of interruption, preferably in a special room devoid of anything which might distract his attention and lessen the omnipresence of interrogation. ${ }^{129}$ Ideally, the interrogator has learned as much as possible beforehand about the alleged offense and about the background and personality of the accused.130 Special tactics for exploiting individual psychic phenomena are used with various types of sus-

Confession Dilemma in the United States Supreme Court, 43 InL. L. Rev. 442, 462 (1948); ABA Statenent 280.

124. See Crooker v. California, 357 U.S. 433, 443-44 (1958) (dissenting opinion); Smith, Public Interest and the Interests of the Accused in the Criminal Process-Reflections of a Scottish Lawyer, 32 TuL. L. Rev. 349, 354 (1958) ; Bader, Coerced Confcssions and the Due Process Clause, 15 BrookLyn L. Rev. 51, 70 (1948). Because charges of coercion are freely bandied about, courts view them skeptically. See, e.g., Stein v. New York, 346 U.S. 156, 181 (1953).

125. See Stein v. New York, supra note 124, at 192; Thomas v. Arizona, 35 U.S. 390, 393 (1958) ; Fikes v. Alabama, 352 U.S. 191, 197-98 (1957).

126. See Fikes v. Alabama, supra note 125, at 197; Watts v. Indiana, 338 U.S. 49, 52-53 (1949); Turner v. Pennsylvania, 338 U.S. 62, $63-64$ (1.949).

127. See MÜNSTERBERG, ON THE Witness Stand 150-53 (1949) (melancholia): Comment, 62 Y AIE L.J. 55, 69 (1952) (pathological accusation); Note, 28 IND. L.J. 374, 380-82 (1953) (generál psychological deviations).

128. See O'Hara, Fundamentals of Criminal Investigation 99 (1956) [hereinafter cited as O'Hara]; Dienstein, Technics for the Crime Investigator 100 (1952) [hereinafter cited as DIENSTEIN] ; KIDD 55-56.

129. Inbau \& Reid 142-47; O'HArA 100-01; KIDd 58, 60; MULbar 11.

130. Inbau \& Reid 148; Mulbar 20; Wilson, Police Planning 315-16 (2d ed. 1957). 
pects. ${ }^{131}$ Above all, the interrogator should not hurry. ${ }^{132}$ Passing time will show the accused that he must be prepared to resist indefinitely. ${ }^{133}$ Many hours may be consumed confronting him with previously gathered incriminating evidence, or developing and underscoring inconsistencies in an original statement. If he is a hardened criminal, he may encounter prolonged proceedings intended to impress him with the dominance and relentlessness of his inquisitors. ${ }^{134}$

\section{The Argument}

\section{The Utility of Prearraignment Interrogation}

Building on the assumption that self-incriminating statements, and therefore interrogation, are indispensable to law enforcement, $M c N a b b$ 's detractors urge that the doctrine prevents interrogation during the only period in which questioning can be effective, the period before arraignment. They claim that, once an individual is brought before a committing officet, the police lose "control" of him and cannot continue their inquiry.135 In the absence of "probable cause," the accused must be set free ${ }^{136}$ and, if "probable cause" can be shown, either he is admitted to bail and immunized from police questioning, or else he is committed to the custody of a United States marshal, who will take him to a jail where, it is asserted, the police cannot subject him to unwanted questioning. ${ }^{137}$ Difficulties engendered by losing "control" over the accused are increased for the police by the magistrate's warning him that he need not make a statement and that any statement he does make can be used against him. ${ }^{138}$ The accused's psychological resistance to interrogation is thus bolstered. Furthermore, the magistrate notifies the accused of his right to retain counsel, ${ }^{130}$ and a lawyer's first step will often be to advise his client to remain silent. ${ }^{140}$ Consequently, the police seek not only an opportunity to question but an opportunity to question before arraignment. ${ }^{141}$

\section{Commentary}

Rule 5(a), as interpreted by the Supreme Court, presumes that any delay allowing police interrogation prior to arraignment represents so great a threat

131. Dienstein 108-15; Kidd 77-186; O'Hara 102-10, 1.12-14.

132. DIENSTein 103; Kidd 74-75; Mulbar 22.

133. See KInd 75.

134. See O'Hara 112. Although a half hour's interrogation may suffice in some cases, others may require a much longer period of inquiry. See INBAU \& REIn 185; 1958 House Hearings 38, 58, 66-67; 1944 Hearings 9. See generally. Horowitz, The Psychology of Confession, 47 J. CrRa. L., C. \& P.S. 197 (1956).

135. See note 8 supra.

136. See note 3 supra.

137. See note 5 supra; 1958 House Hearings 42.

138. See note 2 supra.

139. See ibid.

140. See 1958 House Hearings 36 ; note 213 infra.

141. Id. at 42. 
of coercion that the delay ought to be prohibited whenever feasible. Thus, "unnecessary delay" evokes evidentiary exclusion. Nonetheless, a brief period of questioning probably does not constitute a substantial danger of coercion. The temptation to resort to brutality is ever present, but it would appear a comparatively easy one for the police to resist so long as they have hope of obtaining a statement through interrogation. Once long periods of questioning have proved unsuccessful, however, the patience of the interrogator is likely to become frayed, his better judgment weakened, and the threat of brutality most serious. Moreover, the psychologically coercive potentialities of interrogation appear in large measure a function of its duration. Untrustworthy statements may, of course, be given without any interrogation at all.142 But the Supreme Court has yet to strike down on constitutional grounds a statement elicited solely by means of a short interrogation. ${ }^{143}$ Only as questioning proceeds, increasing its suggestive impact on the accused, whose situation of stress magnifies his suggestibility, does the probability of coercion generally become serious. ${ }^{144}$

Irrespective of the danger of coercion, interrogation must be restricted in order to avoid inordinate harassment of the innocent. Not every arrested person is a criminal offender; and police interrogation is a discomforting if not frightening experience. The wrongly accused, separated from family and friends and detained incommunicado for an indefinite period of time, may be subjected to a grueling ordeal which, even if within the limits of "due process," is undesirable. ${ }^{145}$

Indeed, the $M c N a b b$ doctrine appears in its most salutary aspect as a preventive against police arrests motivated not by "probable cause" but by a desire to interrogate suspects. Arrests of the innocent are inevitable, to be sure, but their frequency is reduced by the requirement that the police, before interfering with an individual's freedom, have probable cause to believe that he has committed or is committing an offense. ${ }^{146}$ The fact that this safeguard

142. Arnold, Psychology Applied to Legal Evidence and Other Constructions of LAw 337 (1913); 1958 House Hearings 3; see Note, 28 IND. L.J. 374, 378-79, 382 (1953).

143. Justice Douglas has suggested construing the $I I c N a b b$ rule as a constitutional one under the "due process" clauses of the fifth and fourteenth amendments. Watts $v$. Indiana, 338 U.S. 49, 56 (1949) (concurring opinion); see 1944 Hearings 29-31.

144. See Sargant, Battle for the Mind 186, 188 (1.957); Note, 28 IND. L.J. 374, 380 (1953).

145. See ABA Statement 13-15.

146. "Probable cause exists where the facts and circumstances within their [the officers'] knowledge, and of which they had reasonably trustworthy information, [are] sufficient in themselves to warrant a man of reasonable caution in the belief that' an offense has been or is being committed." Brinegar v. United States, 338 U.S. 160, 175-76 (1949), quoting from Carroll v. United States, 267 UdS. 132, 162 (1925). To the same effect, see Stacey v. Emery, 97 U.S. 642, 645 (1878); StEvens, ARRest 43 (1930).

When arrest is made upon a warrant, a showing of "probable cause" is a prerequisite to issuance of the warrant. U.S. CoNST. amend. IV; e.g., West v. Cabell, 153 U.S. 78, 
is widely disregarded ${ }^{147}$ does not legalize the infringement of individual rights. And the contention that $M c N a b b$ unwisely prevents the questioning of persons as to whom "probable cause" cannot be shown is essentially an argument for detention on suspicion. ${ }^{148}$ Basically foreign to the common law, ${ }^{149}$ such detention, if available, would encourage wholesale arrests on the flimsiest of evidence ${ }^{150}$ by allowing the police to interrogate in order to establish the "probable cause" which should exist before an accused is taken into custody. ${ }^{151}$ Assuredly, no societal gain through more efficacious law enforcement can justify the arbitrary arrest and questioning of substantial numbers of innocent people. ${ }^{162} M c N a b b$ 's restriction on prearraignment interrogation reduces the likelihood of such treatment, since "probable cause" must be established when an accused is first brought before a committing officer.

The need for prearraignment interrogation might be avoided altogether if the police were allowed to question an accused once a committing officer found "probable cause." 153 The present practice of immunizing an arraigned person

85, 87 (1894); United States v. Kennedy, 5 F.R.D. 310,312 (D. Colo. 1946). For the form of a federal warrant, see Fed. R. CRrnr. P. f(b) (1).

The police must also have "probable cause" to arrest without a warrant. ALI, CoDE of Criminal Procedure 231-38 (1931) (collecting authorities); 1 Alexander, Arrest 441 (1949); 4 Wharton, Criminal Law and Procedure $\$$ 1595-97 (Anderson ed. 1957). In the case of a misdemeanor, an arrest without a warrant may occur only when the crime is committed in the presence of an arresting officer. ALI, CODE of CRIMINAL Procedure 231-34 (1931) (collecting authorities); 1 Alexander, ArRest 435 (1949); 4 WhARToN, op. cit. supra $\$ 1597$. Arrest without a warrant by a federal officer is governed, in the absence of statute, by the law of the state in which the arrest is made. United States v. Di Re, 332 U.S. 581, 589-90 (1948); Johnson v. United States, 333 U.S. 10, 15 n.5 (1948); Seawell v. United States, 243 F.2d 909, 912 (4th Cir. 1957). See Orfield, Warrant of Arrest and Summons Upon Complaint in Federal Criminal Procedure, 27 U. Cinc. L. Rev. 1, 52-54 (1958).

147. American Bar Ass'n Comm. on Lawless Enforcement of Law, Report, 1 Axr. J. Police ScI. 575 (1930); Foote, Safeguards in the Law of Arrest, 52 Nw. U.L. Rev. 16, 27 (1957); Hopkins, Our LAwless Police 61-75 (1931).

148. "Suspicion" in this context is something less than "probable cause." See, e.g., Foote, supra note 147 , at 18.

149. ALI, Code of Crimmal Procenure 236 (1931) (collecting authorities); see note 101 supra. But see Warner, The Uniform Arrest Act, 28 VA. L. REv. 315, 318-19 (1942); note 102 supra.

150. Ninety persons were arrested in a recent dragnet in the District of Columbia. 1958 Serate Hearings 40, 78.

151. This is precisely what is forbidden by Mallory v. United States, 354 U.S. 449, 456 (1957).

152. Police also use vagrancy and similar charges to justify arrests for questioning. See Foote, Vagrancy-type Law and Its Administration, 104 U. PA. L. REv. 603 (1956); Hall, The Law of Arrest in Relation to Contemporary Social Problems, 3 U. CEr. L. Rev. 345, 369 (1936); Note, 59 Y YLE L.J. 1351 (1950).

153. The "probable cause" referred to is the probable cause to prosecute determined at a preliminary hearing at which the accused may present evidence, FED. R. CRIM. P. 5 (c), rather than the evidence needed by the police to justify an arrest without a warrant, see note 146 supra. 
from interrogation does not rest on inviolable principles of law. ${ }^{154}$ The Constitution would appear to permit the suspension of bail pending a brief period of judicially authorized interrogation. ${ }^{155}$ And the Supreme Court has held that the police may question an accused whom a commissioner has committed. . $^{160}$ In fact, prior to the $M c N a b b$ decision, the United States marshals in the District of Columbia-under whose custody the great majority of federally accused persons are placed pending trial-regularly returned them to the police for interrogation. ${ }^{157}$

Nevertheless, law-enforcement authorities contend that, given "probable cause" and an opportunity for postarraignment interrogation, effective inquiry is undercut when the accused is warned that he may remain silent, that anything he says may be used against him, and that he may retain counsel. ${ }^{108}$ If this is so, questioning an accused after he has been advised of his rights by an arraigning commissioner will not solve the difficulties which $M c N a b b$ poses for the police. The committing officer's warnings and the opportunity to retain counsel might, however, be postponed until after a brief period of judicially authorized interrogation. ${ }^{158}$

\section{Additional Arguments}

\section{Arraignment as a Signal to the Accused's Confederates}

Critics of $M c N a b b$ protest that the speedy appearance of an accused in arraignment proceedings serves to warn his confederates that their own criminal activity may have been discovered. ${ }^{160}$ Since much of modern crime springs from highly organized, cooperative effort, and since arraignment is a public proceeding subject to newspaper coverage, many offenders, it is alleged, will benefit from the strict enforcement of rule $5(\mathrm{a}) .^{161}$

Actually, the publicity of arraignment can prejudice the police only when confederates are so unaware of each other's activities that one of them can undergo arrest without his partners knowing it. Moreover, the argument that prompt arraignment aids the underworld leads to the conclusion that incommunicado detention is permissible so long as the fact of arrest can be kept

154. See 1958 House Hearings 42 ; 1944 Hearings 6.

155. See notes 206-09 infra and accompanying text. Cf. Comment, 7 Bufralo L. REv. 427, 433-34 (1958). Under the present procedure, bail is postponed whenever a committing officer is unavailable, since such officers alone have the power to fix bail. 18 U.S.C. $\$ \$ 3041,3141$ (1952) ; 28 U.S.C. $\$ 637$ (1952); FED. R. CRIM. P. 5(b).

156. United States v. Carignan, 342 U.S. 36 (1951).

157. 1944 Hearings 6-7.

158. See 1958 House Hearings 36-37; note 2 supra.

159. See notes 214-18 infra and accompanying text.

When an accused is proceeded against by indictment or information, a commissioner need not warn him of his rights. Fed. R. CRIM. P. 9(c) (1); see United States v. Pickard, 217 F.2d 472, 475 (9th Cir. 1953).

160. 1958 Senate Hearings 35; 1944 Hearings 35; ABA Statenent 4-5.

161. See 1958 Senate Hearings 31, 35. 
secret. Such detention practically suspends the writ of habeas corpus ${ }^{\mathbf{1 6 2}}$ and subjects the accused to the probability of coercion which arises from police detention for indefinite periods of time. On those rare occasions when secrecy is in fact necessary, it could be achieved less horrendously by providing for arraignment in camera. ${ }^{163}$

\section{The Intended Reach of Rule 5(a)}

Opponents of $M c N a b b$ further maintain that the draftsmen of the Federal Rules of Criminal Procedure did not intend that rule 5(a) be enforced by the exclusion of evidence. ${ }^{164}$ This argument finds support in the fact that a provision based on $M c N a b b$ was deleted from the rules as originally proposed. The first preliminary draft stipulated that any statement made by an accused in response to interrogation would be inadmissible as evidence against him if the interrogation occurred during "unnecessary delay." 165 This provision did not appear in the second preliminary draft, was not again considered by the Supreme Court's Advisory Committee, ${ }^{166}$ and was omitted from the rules as approved by the Court. ${ }^{167}$ From this deletion, critics of $M c N a b b$ have inferred that the Advisory Committee sought to nullify $M c N a b b$ itself. ${ }^{168}$

Whether or not this inference is correct, it seems irrelevant. Congress granted the Supreme Court the power to formulate the Criminal Rules, ${ }^{160}$ and the Court appointed the Advisory Committee simply to aid in the task.170 Therefore, even in the face of an implicit Committee repudiation of $M c N a b b$, the intent of the Court must govern. And the Court has declared emphatically that rule 5(a) in no way detracts from $M c N a b b .^{171}$

162. See ABA Statement 13-14.

163. See United States v. Klapholz, 17 F.R.D. 18, 23 (S.D.N.Y. 1955) ; Orfield, Proceedings Before the Commissioner in Federal Criminal Procedure, 19 U. PIrT. L. REv. 489, 563 (1958); ABA STATENIENT 39.

164. 1958 House Hearings 4-5, 178; 1958 Senate Hearings 53-54.

The Federal Rules of Criminal Procedure were drafted by an Advisory Committee appointed by the Supreme Court. Order Appointing Advisory Committee on Rules in Criminal Cases, 312 U.S. 717 (1941); Order, 323 U.S. 821 (1944); Order, 327 U.S. 825 (1946). After being approved by the Court, the Rules were submitted to Congress and have the effect of law. 18 U.S.C. $\$ 3771$ (1952) ; Ochoa v. United States, 167 F.2d 341, 345 (9th Cir. 19.48).

The general approach of the Advisory Committee is discussed in Holtzoff, Participation of the Bar in Itedicial Rule-Making, 3 F.R.D. 165, 166 (1943). An exhaustive history of rule 5 is presented by Orfield, Proceedings Before the Commissioner in Fediral Griminal Procedutre, 19 U. PiTt. L. REv. $489-504$ (1958).

165. FEd. R. CRras. P. 5(-b) (First Preliminary Draft, 1943).

166. Orfield, Proceedings Before the Commissioner in Federal Criminal Procedure, 19 U. Pitr. L. Rev. 489, 502-03 (1958).

167. Order, 323 U.S. 821 (1944). zoff).

168. E.g., S. REP. No. 1478, 85th Cong., 2d 'Sess. 5 (1958) (letter from Judge Holt-

169. 18 U.S.C. $\$ \S 3771,3772$ (1952).

170. 312 U.S. 716 (1941).

171. Mallory v. United States, 354 U.S. 449, 453 (1957) ; Upshaw v. United States, 335 U.S. 410 (1948). 
Furthermore, the purpose behind the Committee's deletion of proposed rule 5 (b) is not at all clear. After the first preliminary draft was published, attacks on the rule were made in the press, letters to the Committee, and judicial conferences. ${ }^{172}$ Much of this criticism came from United States Attorneys and other law-enforcement officials who opposed $M c N a b b$ in strength. ${ }^{173} \mathrm{On}$ the other hand, considerable adverse comment derived not from an overwhelming dislike for $M c N a b b$ but from the fact that the Committee had incorporated a canon of evidence into a set of procedural rules. ${ }^{174}$ This step was deemed unnecessary, for the Supreme Court had already decided $\mathrm{MC}$ $N a b b$, and undesirable, for it crystallized into statute an evidentiary doctrine better left, so it was said, to case-law evolution. ${ }^{175}$ Among the members of the Committee were both friends and foes of $M c N a b b$, and their motives for deleting proposed rule $5(\mathrm{~b})$ were undoubtedly varied. ${ }^{176}$ If they had really intended to overrule $M c N a b b$, they could have proposed a specific provision to that effect rather than content themselves with ambiguous silence. In sum, the deletion of proposed $5(\mathrm{~b})$ was hardly tantamount to disapproving $\mathrm{Mc}$ $N a b b$.

\section{The Congressional Reaction to Mallory \\ The Willis-Keating Bill}

Of the congressional proposals provoked by Mallory, the Willis-Keating Bill lived the longest. In the process, it compiled a colorful history. ${ }^{177}$ The bill as passed by the House provided, first, that any evidence otherwise admissible should not be excluded solely because of "delay" in taking an arrested

172. This material appears in 1 \& 2 Comarents.

173. E.g., 1 id. at 32-38, 39; 2 id. at 328-29, 336a.

174. 2 id. at 327.

175. 1 id. at 29 .

176. Compare Dession, The New' Federal Rules of Criminal Procedure (pt. 1), 55 YALE L.J. 694, 707 (1946), with Judge Holtzoff's view in S. REP. No. 1478, 85th Cong., $2 d$ Sess. 5 (1958). Both men were members of the Advisory Committee.

177. The Willis-Keating Bill read as follows:

(a) Evidence, including statements and confessions, otherwise admissible, shall not be inadmissible solely because of delay in taking an arrested person before a commissioner or other officer empowered to commit persons charged with offenses against the laws of the United States.

(b) No statement, including a confession, made by an arrested person during an interrogation by a law-enforcement officer shall be admissible unless prior to such interrogation the arrested person had been advised that he is not required to make a statement and that any statement made by him may be used against him.

H.R. 11477, 85th Cong., 2d Sess. (1958).

Other bills inspired by the Mallory decision included H.R. 8624, 85th Cong., 1st Sess. (1958) (by Rep. Poff, prohibiting exclusion solely because of delay in arraignment); $S$. 2970, 85th Cong., 2d Sess. (1958) (by Sen. Eastland, same); S. 3325, 85th Cong., 2d Sess. (1958) (by Sen. Morse, providing a preinterrogation procedure for the police); S. 3355, 85th Cong., 2d Sess. (1958) (by Sen. Butler, requiring arraignment within 
person before a committing officer $\mathbf{;}^{178}$ but, second, that no statements elicited from an arrested person before arraignment would be admissible unless the police, prior to questioning him, had advised him that he need not speak and that anything he said could be used against him. The bill was reported out of the Senate Committee on the Judiciary with its first provision amended to read "reasonable delay" instead of "delay."179 Several Senators suggested that the amended provision would not change the meaning of rule 5 (a) as enforced by $M c N a b b$ because "unnecessary" and "unreasonable" are synonymous. ${ }^{180}$ Senator O'Mahoney, the amendment's sponsor, stated that the bill would in no way weaken the command for prompt arraignment, ${ }^{181}$ but that it would not exclude constitutionally obtained evidence unless an unreasonable delay had ensued. 182 Senator Carroll, on the other hand, who supported the O'Mahoney amendment at length, apparently felt that its whole purpose was to frustrate Senate passage of the House bill. ${ }^{183} \mathrm{He}$ and others appeared resigned to some form of anti-Mallory legislation, and sought to confine it to an insignificant change in existing law. ${ }^{184}$ They had their way, for no bill became law.

During the closing days of Congress, a crucial vote in a senatorial campaign against the Supreme Court passed the O'Mahoney amendment 41$39 ;^{185}$ the bill as amended was approved $65-12 . .^{186}$ The House refused to accept the amendment, and the measure went to conference. ${ }^{187}$ There, the

twelve hours of arrest). The Willis-Keating Bill was the only measure to pass either chamber. See N.Y. Times, July 3, 1958, p. 8, col. 6. See generally Hogan \& Snee, The McNabb-Mallory Rule: Its Rise, Rationale and Rescue, 47 Geo. L.J. 1, 33-46 (1958).

A new bill, H.R. 4957, 86th Cong., 1st Sess. (1959), identical to Willis-Keating as above cited, is presently being considered by the full House Committee on the Judiciary after being favorably reported by a subcommittee. 105 CoNG. Rec. D135 (daily ed. March 5 , 1959). Similar bills have been introduced in both chambers, see 27 U.S.L. WEEK 2392 (Gen. Pt. 1959) ; Washington Post \& Times Ferald, March 6, 1959, p. D1, col. 1; H.R. 2918, 86th Cong., 1st Sess. (1959).

178. Compare the Hobbs Bill, note 25 supra.

179. S. Rer. No. 2252, 85th Cong., 2d Sess. (1958).

180. 104 Cong. Rec. 17041, 17046-47, 17081-82, 17095, 17098 (daily ed. Aug. 19, 1958).

181. Id. at 17041-42.

1\$2. Id. at 17041, 17052, 17056. Senator O'Mahoney preferred "unreasonable" to "unnecessary" in regard to the rule of evidence because he felt that "unnecessary" had been given an automatic or mechanical definition by the courts. He was also impressed by the tradition accompanying "unreasonable," which had its roots in the fourth amendment, while "unnecessary" was a newcomer to the scene, making its appearance upon the adoption of rule 5(a). Id. at 17041, 17082. The Senator's history of the word "unnecessary" in its pertinent context is incorrect. "Without unnecessary delay" was read into prompt-arraignment statutes by the courts prior to the adoption of rule 5(a). See note 12 supra.

183. See 104 Cong. Rec. 17056, 17098 (daily ed. Aug. 19, 1958).

184. See $i d$. at 17095-96; $104 \mathrm{id}$. at 18082 (daily ed. Aug. 25, 1958).

185. 104 CoNg. Rec. 171.16 (daily ed. Aug. 19, 1958).

186. Id. at 17125. Amendments proposed by Senator Ervin and Senator Morse were defeated. Id. at 17116-24.

187. Id. at $17125 ; 104$ id. at 17277 (daily ed. Aug. 20, 1958). 
House conferees-evidently after protesting that the O'Mahoney amendment would not overrule but adopt the Mallory decision 188_-succeeded in appending to the Willis-Keating Bill a new proviso which would make "[reasonable] delay .... an element in determining the voluntary or involuntary nature of ... statements or confessions." 189 The proviso, although designed to force the judiciary to read "reasonable delay" as any interval which would not impel constitutional exclusion, ${ }^{190}$ did not seem to change the meaning of the bill appreciably. All it accomplished was a funeral, for, when the bill returned to the Senate, Senator Carroll claimed on a point of order that the conference version contained new matter that had not been "considered in either chamber. ${ }^{191}$ At $4: 10$ in the morning, directly preceding adjournment, Vice-President Nixon sustained the point of order, and the Willis-Keating Bill went dramatically down to defeat. ${ }^{192}$

\section{The Shortcomings of Willis-Keating}

All three forms of the Willis-Keating Bill were inadequate. The Senate's version, by allowing the courts to exclude evidence obtained during an "unreasonable" delay, simply codified $M c N a b b$ with all its ambiguities. ${ }^{103}$ Indeed, the new terminology threatened to jettison the sketchy definition of "unnecessary delay" found in the decisions. The policy behind the McNabb-Mallory rule-essentially one of deterrence-cannot operate successfully unless clear standards enable law-enforcement authorities to know when their conduct will prove illegal and their inquisitorial efforts useless. Otherwise, police seeking to obey the law may violate it unknowingly, infringe upon defendants' rights unnecessarily, and void the convictions of guilty persons unwittingly.

The proviso which the conference committee added did not cure the defects of the Senate amendment. Although apparently designed to restore the substance of the original House measure, the proviso was so poorly drafted that it could easily have been read not as limiting the effect of the Senate amendment but as partially codifying the "due process" prohibition against involuntary confessions. ${ }^{194}$

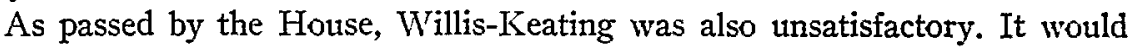
have permitted the police to detain an arrested person for as long as "due process" permits provided they first warned him of his rights. ${ }^{195}$ Such deten-

188. Hogan \& Snee, supra note 177 , at $44-45$.

189. H.R. Rer. No. 2702, 85th Cong., 2d Sess. (1958).

190. See Hogan \& Snee, supra note 177, at 45. The conference report does not make the proviso's purpose abundantly clear See H.R. Rep. No. 2702, 85th Cong., 2d Sess. (1958).

191. See 104 Cong. Rec. 18082-83, 18093-96, 18100-01 (daily ed. Aug. 25, 1958).

192. See $i d$. at 18101.

193. See notes 179-84 supra and accompanying text.

194. See 104 CoNc. Rec. 18082-83 (daily ed. Aug. 25, 1958).

195. See note 177 supra. 
tion would encompass not only the likelihood of unprovable coercion but also an incommunicado holding of the accused in derogation of his right to habeas corpus. ${ }^{190}$ Furthermore, the bill would encourage arrests on suspicion followed by periods of prearraignment detention used to secure evidence upon which the illegal arrests could be justified. While a warning to the accused that he may remain silent and that anything he says can be used against him might bolster his resistance to psychological pressures, a warning, to be effective, should come from a judicial officer rather than the police. Law-enforcement agents who routinely deny coercing confessions could overlook their duty to warn and subsequently swear that a warning was given. More important, an accused frequently will not understand his rights unless they are explained to him at length, and it is highly doubtful that the police, devoted to tracking down criminal offenders, will pause in their headlong quest for information in order to bring home to an ignorant suspect the meaning of his constitutional heritage.

Neither the legislative nullification of $M c N a b b$ without more nor the substitute rule embodied in the original Willis-Keating proposal would adequately secure an accused from illegal arrest and prearraignment coercion. On the other hand, the present operation of the $M c N a b b$-Mallory doctrine needlessly inhibits police questioning whenever a committing officer is readily accessible. In fact, a magistrate's accessibility is a circumstance totally divorced from the threat of coercion which $M c N a b b$ is designed to counter. Rule 5(a), however, by forbidding all "unnecessary delay," invites an evidentiary rule predicated on the feasibility of arraignment. A modification not of $M c N a b b$-Mallory but of the underlying "unnecessary delay" approach is therefore indicated. Otherwise, the fortuitous availability of commiting officers or the chance presence of other circumstances rendering arraignment infeasible, rather than the likelihood of coercion, will continue to determine the admissibility of evidence gleaned through police interrogation.

\section{A Proposed Amendment to the Federal Rules}

\section{Judicially Authorized Interrogation}

At present, evidence may be elicited from an accused between arrest and arraignment provided the evidence is not obtained during a period of "unnecessary delay." Thus geared to rule 5 (a), the $M c N a b b$-Mallory doctrine strikes a random balance between legitimate inquiry and constitutional protection. Were interrogation instead forbidden altogether except after arraignment and then permitted under circumstances favorable to productive, noncoercive inquiry, a more rational balance would be achieved. Accordingly, the Federal Rules of Criminal Procedure should be amended to prohibit the police from questioning an accused prior to his appearance before a committing officer. In addition, the Rules should empower the commissioner, on find-

196. See ABA Statearent 13-14. 
ing an arrest legal, first, to inform the arrested person of certain constitutional and statutory rights and, second, to remit him to the police for a limited period of questioning. The present arraignment procedure of rule $5(\mathrm{~b})$ as well as the rule $5(\mathrm{c})$ preliminary hearing should await the end of this period. 197

\section{Immediate Arraignment}

Rule 5(a) should be revised so that the police must cause an arrested person to be arraigned as soon as he can be physically transported to a committing officer. Only a pressing need for medical attention should justify delay. Prior to arraignment, the police should be allowed to ask the accused no more than his name and address. ${ }^{108}$ Further questioning should be illegal, and no statement gleaned during an illegal interrogation should be admissible as evidence. The police would not be responsible for warning the accused of any rights. Their single postarrest task would be to convey him immediately to a commissioner.

To ensure compliance with these requirements, the commissioner should ask an accused whether he made any statements to the police and, if so. whether his statements were prompted by interrogation or other inducement. A threshold confession or admission would therefore be quickly discovered, and would be branded inadmissible if elicited by the police. In fact, any postarrest, prearraignment statement which the accused does not voluntarily repeat before the magistrate should be excluded from evidence, for substantial doubt would exist as to how it was obtained. Manifestly, the prearraignment time during which the police would have unsupervised control over the accused would be made as short as possible. And, since prearraignment confessions obtained through interrogation would be inadmissible, the police would have little incentive to hold an accused incommunicado for any period of time. For the same reason, should a prompt appearance before a committing officer be physically impossible, the ensuing period of detention would not invite coercion. Thus, a grave defect in $M c N a b b$ would be remedied: a safeguard would exist against intensive interrogation in the event delay became "necessary."

197. The present procedure is outlined in the text accompanying notes 1-7 supra.

198. For a definition of arrest, see text at note 101 supra. Prior to arresting a person, the police would be permitted to question him. But once they restrict the freedom of the man they have accosted, they must be deemed to have made an arrest. This scheme permits questions until the suspect desires to leave the scene. Once his departure is barred or he is taken away to another place by the police, questioning must cease.

Under English practice, questioning is inhibited once arrest is made, but the time uf arrest depends on when the policeman decides to charge the accused. Royal Commission on Police Powers and Procedure, Report, CMr. No. 3297, at 70 (1929) (Judges' Rules): Smith, Public Interest and the Interests of the Accused in the Criminal Process-Reflections of a Scottish Lawyer, 32 TuL. L. Rev. 349, 352-53 (1958). Scottish practice is more rigid. See $i d$. at 360-61. 
The commissioner should also determine, on the face of police testimony alone, whether or not the arrest was legal. If the accused was unlawfully arrested, the commissioner must of course release him. This prompt judicial determination of the lawfulness of arrest would preclude the detention and interrogation of persons wrongfully apprehended. But if the commissioner finds that the arrest was proper, he ordinarily should remit the accused to police custody for a limited period of interrogation. ${ }^{199}$

\section{Judicially Authorized Postarraignment Interrogation}

The temporary return of the accused to police custody after arraignment would provide an opportunity for interrogation of limited duration. Since the period of interrogation would be judicially set beforehand, the probability of coercion would be slight. The police should not be allowed to retain any accused longer than three hours; and the commissioner should restrict the interval more severely if the accused appears to show unusual fear, anxiety or emotional conflict. Three hours is, to be sure, an arbitrary figure. But it seems a reasonable one representing a sufficiently brief span of time to forestall psychological coercion through intensive questioning. Certainly, three hours of questioning would not violate any precepts of fundamental fairness ${ }^{200}$ _especially in view of the fact that only the total exclusion of all statements made in custody would guard against instantaneous, physical brutality.

Before remitting the accused, the commissioner should tell him that the police may not in any way compel him to speak or to answer questions against his will. The commissioner should be at great pains to make this caution clear. He should also tell the accused that the period of interrogation is limited, that the police must and will return him to the commissioner after a specified length of time has elapsed, and that no subsequent period of police interrogation will ensue. The accused should be encouraged to talk to the police if he wants to be helpful or to confess or to try to clear himself; but the accused should be urged not to answer questions-and told he need not do so-if he would prefer to say nothing. ${ }^{201}$

199. In exceptional cases, the commissioner might determine that any police interrugation at all would coerce the particular accused or induce him to make false statements. No questioning should then be permitted.

200. Continuous interrogation held coercive by the Supreme Court has always been carried on for a period far longer than three hours. See, e.g., Fikes v. Alabama, 352 U.S. 191 (1957); Leyra v. Denno, 347 U.S. 556 (1954); Watts v. Indiana, 338 U.S. 49 (1949).

201. The commissioner's role in this regard is similar to that of an "ideal" lawyer. "Officers may investigate, or even arrest, an innocent person or a guilty one whose conscience prompts him to disclose the truth. In such event, it is not so unusual as is jopularly supposed that a lawyer 'worth his salt' does advise his accused client to make a full disclosure of all facts and thus assist in the solution of the crime under investigation." State v. Braasch, 229 P.2d 289, 295 (Utah 1951) (concurring opinion), cert. denied, 342 U.S. 910 (1952). 
The commissioner's warnings would make it.highly unlikely that an accused would give untrustworthy confessions for fear that, unless he spoke, he would be detained indefinitely or subjected to violence. Further warnings would be unnecessary. at this point and would unduly inhibit voluntary confession. No need exists to advise the accused that anything he says may be used against him. ${ }^{202}$ For an. individual who wants to confess in order to appease a desire for self-punishment, knowledge that his statements may be used against him would merely encourage him to confess falsely. And counseling the accused that he may not be compelled to speak should eliminate the danger of a confession elicited through fear. Notifying the accused of his right to counsel would also be premature. The magistrate's caution should suffice to prevent falsification; and an attorney's assistance would not further ensure veracity. ${ }^{203}$

\section{Postinterrogation Procedure}

At the end of the prescribed interval, questioning would end; and the police would promptly return the accused to the committing officer, who should then ask him if he has made any statements to the police and, if so, under what circumstances. If the accused alleges violence, his person should be immediately inspected. If the accused acknowledges making an oral confession which, for want of time, was not transcribed, the commissioner should ask him whether he is willing to have the confession taken down by a stenographer. Should the accused agree, transcription should proceed forthwith, and the accused permitted to sign the confession. These preliminaries (if any) dispensed with, the commissioner should carry out the requirements of rules 5 (b) and 5(c). He should advise the accused of his right to counsel and warn him that his statements can be used against him. Further questioning by the police would be prohibited unless the accused voluntarily agreed to submit to it. If charged with a bailable offense, he should be admitted to bail. And if he is committed, the marshal should take him to jail, not to police headquarters.

\section{Accessibility of Committing Officers}

To be effective, a procedure calling for the speedy judicial control of arrested persons dictates that committing officers be readily accessible. Prompt judicial supervision over the detention of persons arrested in the middle of the night or on a holiday weekend is no less important than similar supervision when arrests occur during usual professional hours. In the District of Columbia (where federal officers investigate and prosecute all the commonlaw crimes), the availability of a committing officer twenty-four hours of every day in the year is essential to the adequate protection of citizens' rights. ${ }^{204}$ And in large metropolitan areas where arrests by federal agents are

202. See notes 216-18 infra and accompanying text (constitutional questions).

203. See notes 212-15 infra and accompanying: text (constitutional questions).

204. See note 77 supra. 
frequent, a committing officer should likewise be on duty all the time. In every federal judicial district, at least one Crnited States commissioner should be available at any hour. The cost of providing the extra commissioners is a small price to pay for the efficient and equitable administration of criminal justice. $^{205}$

\section{Constitutional Implications}

The suggested changes in the procedure between arrest and the preliminary hearing would be constitutionally permissible.

Right to Bail. A reasonable delay in admitting an accused to bail does not transgress the eighth amendment's prohibition against excessive bail. ${ }^{206} \mathrm{By}$ implication, the amendment may accord a right to bail in certain instances, ${ }^{207}$ but a brief delay would not compromise that right. That speed is of secondary constitutional importance is shown by the fact that the power to fix bail inheres not in the police but in judicial officers. ${ }^{208}$ And at present, bail is postponed whenever a commissioner is unavailable. To contend that an accused, once brought before a magistrate in a noncapital case, has a right to bail without delay is to wander far from the language of the eighth amendment and even from its implications. A brief delay in bail would neither impair a defendant's preparation of his case nor, if administered uniformly, contradict the presumption of his innocence. ${ }^{209}$

Right to Connsel. Under the suggested procedure, the accused would not be told of his right to retain counsel until after being questioned by the police. This delay would comport with the ruling that the right to counsel in federal cases does not attach until the accused is asked to plead in court. ${ }^{210}$. And

205. For an exposition of the commissioner's functions and responsibilities, see U.S. Juntciar. Conference, Comm. on U.S. Commissioners, Manual for United States CoMmisstoners (rev. ed. 1948). For a discussion of his compensation, see generally Hearings an H.R. 2460, H.R. 2461, H.R. 2462, H.R. 2464 Before a Subcommittee of the House Committee on the Judiciary, 79th Cong., 2d Sess., ser. 15 (1946); Hearings on H.R. H127, H.R. 412S, H.R. 4129, H.R. 4130, H.R. 4131, H.R. 4132 Before a Subcommitte of the House Cummittee on the Judiciary, 78th Cong., 2d Sess., ser. 19 (1944).

206. U.S. Const. amend. VIII.

207. See Lnited States v. Motlow, 10 F.2d 657, 659 (7th Cir. 1926) ; Comment, 51 Mreni. L. Rev. 389, 394 (1953). Since the right to bail before federal conviction in a noncapital case was granted by statute predating the Bill of Rights, the presence or absence of a constitutional requirement has received little judicial discussion. See ibid.; Comment, 20 U. CHI. L. Rev. 330, 331 (1953).

208. See 18 U.S.C. $\$ 3141$ (1952); 28 U.S.C. $\$ 637$ (1952); FED. R. CRIM. P. 5 (b).

271\%. On the purposes of bail, see Heikkinen v. United States, 208 F.2d 738, 742 (7th Cir. 1953); United States ex rel. Rubinstein v. Mulcahy, 155 F.2d 1002, 1004 (2d Cir. $1946)$.

210. See note 2 sutra; Michener v. Johnston, 141 F.2d 171 (9th Cir. 1944); Evans v. Kives, 126 F.2d 633, 641 (D.C. Cir. 1942); Robinson v. Johnston, 50 F. Supp. 774 (N.D. Cal. 1943). Even when asked to plead, the accused may not have a right to counsel. Hiatt v. Gann, 170 F.2d 473 (5th Cir. 1948); Wilfong v. Johnston, 156 F.2d 507 (9th Cir. 1946); McJordan v. Huff, 133 F.2d 408 (D.C. Cir. 1943). 
"due process" guarantees require counsel only when the absence of a lawyer's assistance would prevent an accused from receiving a fair trial. ${ }^{211}$ The Supreme Court has held that lack of counsel does not, without more, render a confession constitutionally inadmissible. ${ }^{212}$ Surely, justice is not denied by a brief period of police interrogation which, though the accused has no counsel, is hedged about with safeguards designed to assure that the accused's statements are reliable and voluntary. In this context, an attorney's efforts to impose silence, if intended to prevent an accused from volunteering incriminating evidence, would frustrate, not facilitate, the course of justice.213

Privilege Against Self-Incrimination. While involuntary statements may be held inadmissible as violating the privilege against self-incrimination, ${ }^{214}$ the police are not constitutionally obliged to notify an accused of the privilege prior to interrogating him. ${ }^{215}$ Some courts have gone so far as to allow in evidence admissions implied by the silence of the accused in the face of incriminating accusation. ${ }^{218}$

To afford meaning to the privilege during police interrogation as well as to prevent false statements induced by fear, the accused should be advised that the police may not compel him to speak, and that he may refuse to answer any

211. Alexander v. United States, 136 F.2d 783 (D.C. Cir. 1943) ; McJordan v. Huff, supra note 210; Wood v. United States, 128 F.2d 265 (D.C. Cir. 1942) ; cf. Crooker v. California, 357 U.S. 433 (1.958).

212. E.g., Crooker v. California, supra note 211 .

213. To bring in a lawyer means a real peril to solution of the crime, because, under our adversary system, he deems that his sole duty is to protect his client-guilty or innocent-and that in such a capacity he owes no duty whatever to help society solve its crime problem. Under this conception of criminal procedure, any lawyer worth his salt will tell the suspect in no uncertain terms to make no statement to police under any circumstances.

Watts v. Indiana, 338 U.S. 49, 59 (1949) (concurring opinion per Jackson, J.). But see Crooker v. California, 357 U.S. 433, 443-46 (1958) (dissenting opinion); Note, $44 \mathrm{Kr}$. L.J. 103-04 (1955).

214. Bram v. United States, 168 U.S. 532 (1897) ; see Brown v. Walker, 161 U.S. 591, 596-97 (1896) ; McNabb v. United States, 318 U.S. 332, 348-49 (1943) (dissenting opinion). Since Bram, the Supreme Court has not utilized the self-incrimination clause to exclude confessions and admissions obtained by the police. See note 15 supra. Bram's rationale is of questionable persuasiveness. See 3 Wigmore, Evidence $\$ 823$, at 250 n.5 (3d ed. 1940).

215. Turner v. United States, 222 F.2d 926 (4th Cir. 1955) ; United States v. Heitner, 149 F.2d 105 (2d Cir. 1945); Morton v. United States, 147 F.2d 28 (D.C. Cir.), cert. denied, 324 U.S. 875 (1945); cf. Wilson v. United States, 162 U.S. 613 (1896) (commissioner's failure to warn not determinative of admissibility); Powers v. United States, 223 U.S. 303 (1912) (same).

216. Rocchia v. United States, 78 F.2d 966 (9th Cir. 1935) ; Dickerson v. United States, 65 F.2d 824 (D.C. Cir. 1933), cert. denied, 290 U.S. 665 (1933). Today, however, the majority of federal courts have espoused the opposing viewpoint. Helton v. United States, 221 F.2d 338 (5th Cir. 1955) ; United States v. Lo Biondo, 135 F.2d 130 (2d Cir. 1943) ; Yep v. United States, 83 F.2d 41 (10th Cir. 1936) ; See Note, 40 Mrnn. L. Rev. 598 (1.956); Note, 5 Stan. L. Rev. 459, 470 (1953). 
and all questions. No further caution seems necessary. Admittedly, a warning that anything he says may be used against him would impress an arrested person with the gravity of his situation. ${ }^{217}$ But this advice might also stifle a desire to confess. ${ }^{218}$ Furthermore, anyone who appreciated the seriousness of his crime will appreciate the effects of its discovery. The guilty accused who fails to recognize the extent of his misconduct does not merit after-the-event advice apprising him of his error. And the wrongly accused, though ignorant of the significance of police interrogation, should not be in danger of incriminating himself, since truthful answers would serve to exonerate rather than implicate him.

\section{CONCLUSION}

$M c N a b b$ 's inadequacy as a defendant's shield lies deeper than the present uncertainty over what evidence must be excluded. The origin of the $M c N a b b$ doctrine and the method by which it operates are the source of its limitations. Through evidentiary exclusion, the Supreme Court has sought to eliminate frequently unprovable constitutional violations emanating from intensive interrogation between arrest and arraignment. The doctrine assumes that sustained interrogation too easily and too frequently leads to coercion; and that coercion is more likely to occur before arraignment than after. It further assumes that rule $5(\mathrm{a})$, in requiring that prearraignment detention be no longer than necessary, evidences a congressional design of protecting arrested persons against the probability of coercion during that interval. Accepting these assumptions, the Court has rendered violations of the rule unprofitable-even prejudicial-to criminal investigators. The $M c N a b b$-Mallory doctrine has thus developed not as an independent judicial weapon for protecting defendants against the danger of prearraignment coercion, but as a judicial method of enforcing a congressional attempt to provide such protection. Hence, the Court's rule of exclusion is only activated when rule $5(\mathrm{a})$ is violated. $M C$ $N a b b$ 's shortcomings as a shield against coercion are therefore a function of rule $5(a)$ 's deficiencies.

If the oft-repeated purpose of $M c N a b b^{210}$ were effectuated, the Supreme Court would forbid any interval long enough to allow the police to undertake

217. See Royal Commission on Police Powers and Procedures, Report, CMD. No. 3297 , at 28 (1929). This report notes that the "constable's caution" was originally given by a magistrate to whom the constable brought the accused immediately upon arrest. Id. at 142. The purpose of the caution was to insure the voluntariness of the accused's statement by showing the court that he knew that he was under no obligation to speak or incriminate himself. Ibid. Indeed, the Commission's suggested caution omits reference to the fact that anything said by the accused could subsequently be used against him. Rather, he is to be told to be careful what he says. Id. at 29.

218. See Letter from English Policeman on Use of Judges' Rulles, in SELECTED WRItrngs on the LAW of Evidence AND TrLal 845 (Fryer ed. 1957) (ignorance of law leads to incriminating statements). But see Sargent, Battle for tHE Mind 191 (1957).

219. See note 15 supra. 
intensive interrogation. A shorter period would not create the same probability of coercion nor require the added deterrent of evidentiary exclusion. But federal prompt arraignment legislation is not devoted exclusively to the elimination of coercion. Rule 5(a)'s command permits a reasonable delay occasioned by the unavailability of a magistrate or by other circumstances which render the prompt production of the accused impracticable. ${ }^{220}$ Consequently, a lawful delay could afford ample opportunity for intensive interrogation leading to constitutional delicts. Operating as it does upon the violation of a statute which condones delay for reasons of practicality, $M c N a b b$ 's protection against coercion is necessarily incomplete.

If the policy behind $M c N a b b$ were divorced from rule 5(a), that policy would exclude evidence in all cases in which an opportunity for prearraignment coercion existed. The resulting interference with police interrogations would pose a serious threat to effective law enforcement. The solution to this problem is not, however, to overrule $M c N a b b$-Mallory by legislation and thereby open the door to illegal arrests and coercive prearraignment detention. Protection must be maintained against the abuses which may frequently occur while an arrested person is exclusively under the control of the police. Accordingly, the Federal Rules of Criminal Procedure should be amended to proscribe prearraignment interrogation altogether and to provide instead for postarraignment questioning subject to judicial supervision minimizing the probability of coercion. Since interrogation would then occur only after the legality of an arrest had been judicially determined, the unjustified harassment of innocent persons would be inhibited.

The suggested procedure may well prove less than ideal for the police. Nevertheless, the traditions of our free society dictate that efficiency in law enforcement be sacrificed whenever a danger exists of undue imposition on the innocent and of unprovable constitutional violations against innocent and guilty alike. ${ }^{221}$ More positively, the recommended procedure will enhance both the clarity of the prompt-arraignment requirement and the protection afforded arrested persons against improper police activities. The opportunity for interrogation, lost in the prearraignment period, is restored at a juncture when coercive activity is less likely to occur. Hopefully, this comprehensive overhaul of present legislation and case law would strike a proper balance between the need for effective law enforcement and the right of the people to be secure from the lawlessness of an overzealous or undisciplined police.

220. See text at notes $77,79,84$ supräa.

221. E.g., ABA STateMent 8. 